EUROPEAN CENTRAL BANK

WORKING PAPER SERIES

NO. 358 / MAY 2004

\title{
DID THE PATTERN OF AGGREGATE EMPLOYMENT GROWTH CHANGE IN THE EURO AREA IN THE LATE 1990s?
}
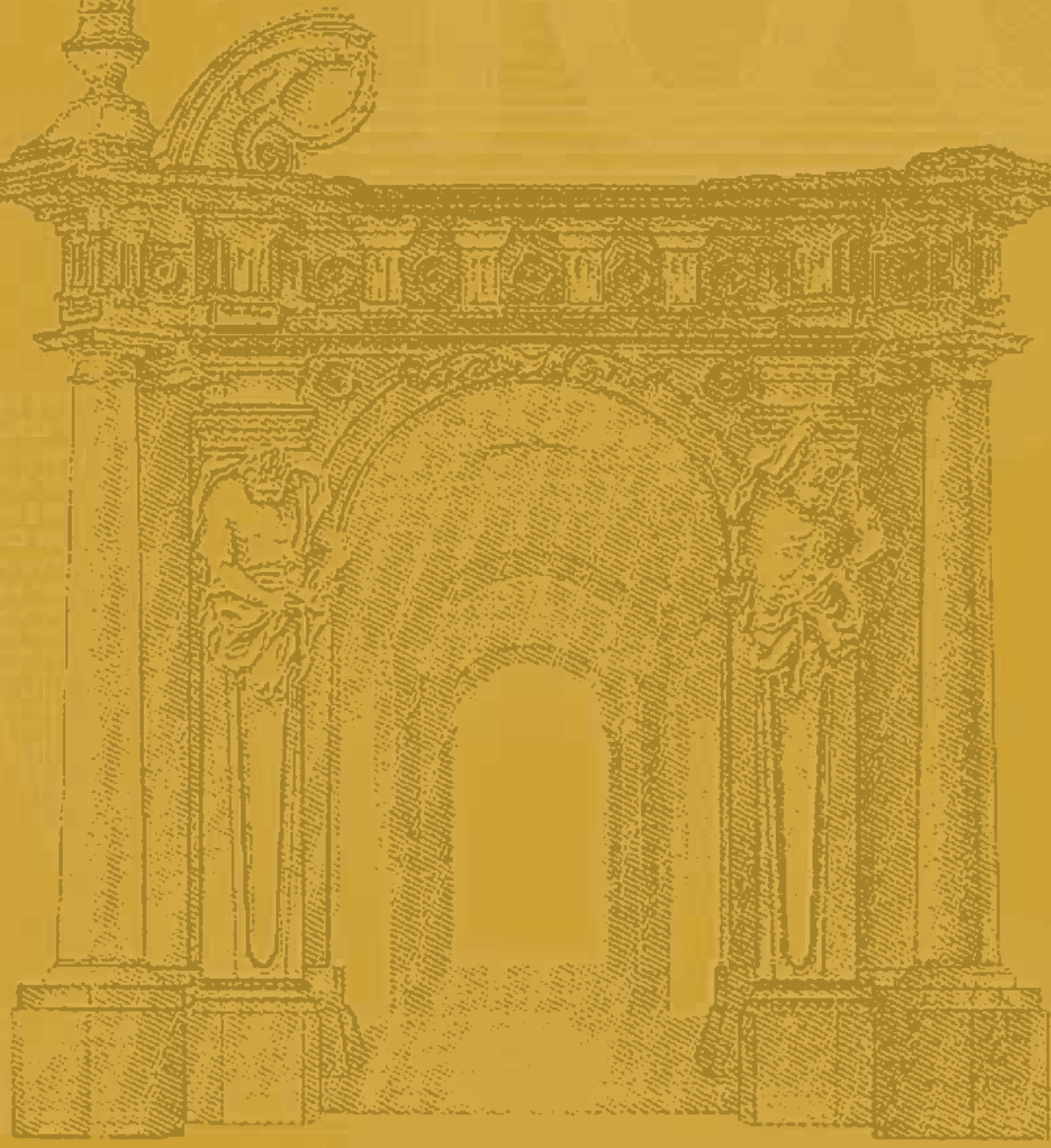


\author{
DID THE PATTERN \\ OF AGGREGATE \\ EMPLOYMENT \\ GROWTH CHANGE \\ IN THE EURO AREA \\ IN THE LATE 1990s?'
}

by Gilles Mourre ${ }^{2}$

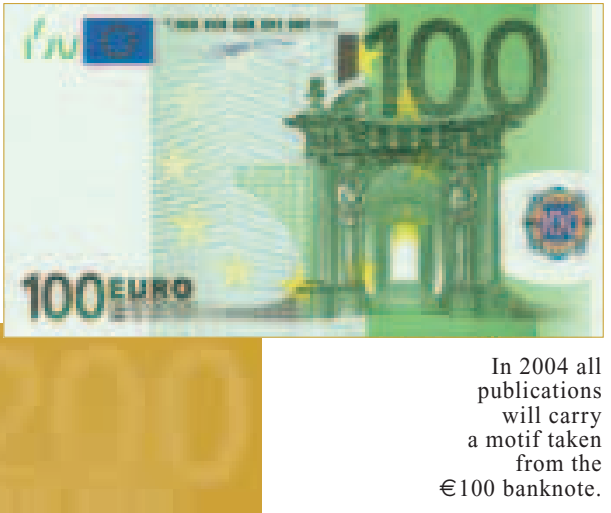

This paper can be downloaded without charge from http://www.ecb.int or from the Social Science Research Network electronic library at http://ssrn.com/abstract_id $=533027$. 


\section{드 European Central Bank, 2004}

\section{Address}

Kaiserstrasse 29

60311 Frankfurt am Main, Germany

Postal address

Postfach 160319

60066 Frankfurt am Main, Germany

Telephone

+496913440

\section{Internet}

http://www.ecb.int

Fax

+496913446000

Telex

411144 ecb d

All rights reserved.

Reproduction for educational and noncommercial purposes is permitted provided that the source is acknowledged.

The views expressed in this paper do not necessarily reflect those of the European Central Bank.

The statement of purpose for the ECB Working Paper Series is available from the ECB website, http://www.ecb.int.

ISSN 1561-0810 (print)

ISSN 1725-2806 (online) 


\section{CONTENTS}

Abstract 4

Non-technical summary 5

1. Introduction 7

2. Estimation of a standard employment equation 8

2.1 Theoretical framework 8

2.2 Data used 10

2.3 Estimation method 10

3. Is there any evidence of a structural change in recent years?

3.1 Evidence of a break in the standard employment equation for the euro area

3.1.1 Quality of the dynamic simulation and the forecasting performance when allowing for a break

3.1.2 The role of traditional determinants, when allowing for a break

3.2 Robustness of the break while considering hours worked or employment in full-time equivalents

3.3 Taking account of heterogeneity across countries

4. What factors may account for a change in aggregate employment pattern in recent years?

4.1 Changes in the sectoral composition of euro area employment

4.2 The importance of labour market institutions

4.3 The role of active labour market policies

4.4 The role of structural changes in explaining cross-country differences in recent employment performance

Conclusion

References

Figures and tables

Annex

European Central Bank working paper series 


\begin{abstract}
The paper examines whether the pattern of growth in euro area employment seen in the period 19972001 differed from that recorded in the past and what could be the reasons for that. First, a standard employment equation is estimated for the euro area as a whole. This shows that the lagged impact of both output growth and real labour cost growth, together with a productivity trend and employment "inertia", can account for most of the employment developments between 1970 and the early 1990s. Conversely, these traditional determinants can only explain part of the employment development seen in recent years (1997-2001). Second, the paper shows sound evidence of a structural break in the aggregate employment equation in the late 1990s. Third, the paper provides some tentative explanations for this change in aggregate employment developments, using in particular country panels of institutional variables and of active labour market policies but also cross-sectional analyses. Among the relevant factors likely to have contributed to rising aggregate employment in recent years are changes in the sectoral composition of euro area employment, the strong development of part-time jobs, lower labour tax rates and possibly less stringent employment protection legislation and greater subsidies to private employment.
\end{abstract}

JEL Classification numbers: C2, E24, H50, J23.

Key words: Euro area; Aggregate employment; Demand for labour; Labour market institutions; Active labour market policies. 


\section{Non-technical summary}

The ratio of employment growth to real GDP growth indicates that real GDP growth was more job intensive in the euro area over recent years, compared with the late 1980s. The aim of this paper is to explain the high employment growth observed in 1997-2001 by means of a standard labour demand equation and to see whether the pattern of aggregate employment in the euro area has changed in recent years. Compared to the late 1980s, the strong growth in employment observed between 1997 and 2001 is partly explained by a buoyant, albeit somewhat lower, economic growth and by much lower labour cost growth.

However, the standard employment equation failed to fully account for the good employment performance observed in the euro area in 1997-2001. The introduction of a break from 1997 onwards turns out to be statistically very significant, improves greatly the quality of the dynamic simulation and increases the stability of the equation. The forecasting performance of the equation also improves strongly. This break may be interpreted as the additional employment growth recorded between 1997 and 2001 which cannot be explained by traditional determinants. Although the choice of the starting date of the break is somewhat arbitrary, its statistical significance is maximised when it starts in 1997.

When the employment equation is re-estimated with employment measured in terms of full-time equivalents and hours worked instead of the number of people employed, the break is still significant, although of a lesser magnitude. This indicates that developments in part-time employment have contributed to the strong employment performance in the 1990s but cannot fully account for the break in labour demand in the euro area.

Taking account of heterogeneity across OECD countries, panel data estimates show that most euro area countries (representing almost two thirds of euro area employment) have experienced a positive break in their aggregate labour demand since 1997. However, five euro area countries, including Germany, did not record any significant change in their employment equation in the late 1990s. No positive break is significant for countries outside the euro area. Panel data estimates broadly confirm the timing of the break, starting in around 1997, although the precise dating varies slightly across countries.

In addition to part-time developments, three possible causes for the change in the aggregate labour demand are examined: changes in the sectoral composition of euro area employment, developments in labour market institutions and the impact of active labour market policies. A simple accounting exercise indicates that the average annual growth rate of employment in the period 1997-2001 would have been 0.2 percentage point lower if the sectoral composition of employment had remained the same as in 19861991. Therefore, the higher weight of fast growing and job-intensive sectors, such as market-related services, in the late 1990s compared to the past, is likely to have contributed to fostering employment growth in recent years.

Albeit difficult to show clearly, labour market reforms and changes in institutions in many euro area labour markets may also have played a role in the recent good employment performance in the euro area. Panel data estimates suggest that total taxes on labour negatively affect employment growth. More mixed 
evidence suggests that employment protection legislation may reduce employment growth, whilst the level of bargaining coordination is found to be positively correlated with employment. As a result, the decline in total labour tax rates, in particular on low-wage employees, is likely to have positively influenced job creation.

Active labour market policies might also contribute to explaining the good employment performance recorded in the recent period. However, the results coming from tentative panel data estimates appear very mixed and display a low level of statistical significance. The aggregate expenditure devoted to public employment services and labour market training are not significant. While subsidies to private employment may be positively related to the employment rate, the impact of direct job creation in the public or non-profit sectors is clearly insignificant. The effect of measures for youth employment does not come out clearly.

The role of structural changes may be highlighted further by relating the cross-country differences observed in the employment pattern since 1997 to changes recorded in the sectoral composition of employment, institutions and active labour market policies in the second half of the 1990s. A clear negative relationship emerges between the tax wedge and the presence of a positive break in recent employment performance. Although the other variables are less tightly linked to the presence of positive break in employment pattern, the cross-country analysis confirms that the impact of changes in the sectoral composition of employment is correlated to employment performance. The strong decline in employment protection legislation in some countries may also explain partly their good employment performance. Moreover, part-time employment rate and subsidies to regular employment in the private sector may have helped improve employment performance in the late 1990s in some countries. Conversely, other institutions such as unionisation, benefit replacement rate, benefit duration or most active labour market policies (public employment services, labour market training and direct job creation in the public sector) do not display any obvious link with the employment performance in euro area countries in the late 1990s. These cross-country results broadly support the general findings arising from panel data analysis.

Overall, part-time employment developments, changes in the sectoral composition of employment and decreasing labour tax rates are good candidates to explain at least partly the break in aggregate employment equation seen in the late 1990s. 


\section{Introduction}

Until recently, the emphasis in the economic literature to account for the improvement in labour markets in Europe in 1997-2001 was mainly put on the decline in structural unemployment. It has been argued that overly rigid institutional structures have prevented the necessary adjustment to changes in the economic environment, thereby leading to higher or more persistent unemployment (Scarpetta, 1996; Nickell 1997; Layard and Nickell, 1998; Morgan and Mourougane, 2001). Blanchard and Wolfers (2000) attribute the rise in unemployment in Europe to the interaction of institutions with adverse macroeconomic shocks.

More recently, several studies have dealt with employment growth directly to shed some light on the strong improvement of labour market performance in many European countries in the late 1990s. From a descriptive point of view, Duchêne and Jacquot (1999) investigate whether a break occurred in the trend growth rate of labour productivity per person employed during the first half of the 1990s in the main OECD countries and whether such a break could be accounted for by changes in relative factor costs or in the number of hours worked. Some other studies have focused on specific aspects to explain the improvement in net employment creation, such as wage discipline in EMU (Pichelmann, 2001) or the change in employment composition (ECB, 2002a). Some more comprehensive studies have attempted to survey all the changes capable of accounting for the higher job intensity in Europe (European Commission, 2000; Decressin et al., 2001; Garibaldi and Mauro, 2002). The geographic focus varies across these studies (EU countries, large euro area countries or OECD countries). This paper continues in this vein by analysing the determinants of employment for the euro area as a whole, while not neglecting heterogeneity across countries. From a methodological point of view, the paper follows that of Fagan, Henry and Mestre (2001), who estimated an aggregate dynamic employment equation for the euro area with an error correction mechanism. While Fagan et al. ran their equation up to 1997, this article focuses on the pattern of employment in recent years.

The employment rate in the euro area, at almost $64 \%$ in 2001, was considerably lower than in the United States (nearly 75\%). The period 1997-2001 however saw a protracted period of sustained employment growth, which led to a fall in unemployment despite a strong increase in the labour force. ${ }^{3}$ Total employment has grown at an average year-on-year rate of 1.5\% from 1997 to 2001, compared with a decline of $0.2 \%$ between 1990 and 1997. This corresponds to an increase of around 7 million in the number of persons employed, whereas earlier in the 1990s, by comparison, employment fell by over 1 million. This strong employment growth is also noticeable when compared with the previous period of strong growth, registered in the late 1980s. Since the late 1960s, as seen in Table 1, the average growth rate recorded in the late 1990s is only comparable to that recorded in the second half of the 1980s $(1.4 \%)$. However, the ratio of employment growth to real GDP growth indicates that real GDP growth was more job intensive in the recent period, at 0.6, compared with 0.4 in the late 1980s. Likewise, the ratio of employment growth to real GDP growth became higher in the late 1990s in the euro area than that in the

\footnotetext{
${ }^{3}$ See, for example, "Labour force developments in the euro area since the 1980s", Véronique Genre and Ramón GómezSalvador, July 2002, ECB Occasional Paper No. 4.
} 
US and the UK. By contrast, this ratio was lower than in the US during past periods of expansion and also lower than that in the UK in the late 1980s.

What accounts for this development? This paper argues that the traditional determinants (GDP growth, labour cost developments, trend productivity) do not fully explain the strong employment growth recorded in the euro area in the recent period. Sound econometric evidence, based mainly on time-series analysis, but also on panel data analysis, suggests that the recent employment performance is related to a structural change in aggregate employment behaviour in the euro area. Looking further, in order to explain the factors underlying this change, a panel of time-varying institutions and measures of active labour market policies is used. This latter methodological approach can be associated with the branch of the literature initiated by Scarpetta (1996) and extended by Belot and van Ours (2000) and Nickell et al. (2001). These articles used cross-sectional or pooled time series data on indicators of labour market performance and labour market institutions to account for unemployment differentials across countries. However, the results found using institutional variables are often unclear or not robust, partly due to measurement problems.

The rest of the paper is structured as follows. Section 2 presents a standard employment equation, estimated for the euro area as a whole. Section 3 shows the existence of a structural break in the aggregated employment equation in the late 1990s. Section 4 provides some tentative explanations for this change, using in particular country panels of institutional variables and of active labour market policies as well as cross-sectional analysis.

\section{Estimation of a standard employment equation}

\subsection{Theoretical framework}

A CES production function with two production factors and constant returns to scale, proposed by Arrow et al. (1961), provides a simple and standard analytical framework to highlight the effect of the main determinants of labour demand:

$$
Y=\left[\alpha\left(a_{t} L_{t}\right)^{\frac{\sigma-1}{\sigma}}+(1-\alpha) K_{t}^{\frac{\sigma-1}{\sigma}}\right]^{\frac{\sigma}{\sigma-1}}
$$

with Y standing for output, $L$ for labour, $K$ for capital, $a$ for labour productivity ${ }^{4}, \alpha$ for the labour-intensity of the method of production and $\sigma$ for the elasticity of substitution between effective labour $(a L)$ and capital. Then, the first order condition of firm's profit maximisation leads to equate the marginal labour productivity to real compensation per employee $w / p$. This leads to the following expression:

$$
\frac{w}{p}=\alpha a_{t}^{\frac{\sigma-1}{\sigma}} L_{t}^{-\frac{1}{\sigma}} Y_{t}^{\frac{1}{\sigma}}
$$

\footnotetext{
${ }^{4} a$ represents the labour efficiency. It can also be seen as the degree of labour-augmenting technical progress (i.e. Harrod-neutral technical progress).
} 
We suppose conventionally that labour productivity growth is constant and positive with $\log a t=\beta . t$ and $\beta>0$, reflecting trend technological progress. After rearranging and writing in logarithms, we end up with:

$$
\log L t=\log Y t-\sigma \log (w / p)-(1-\sigma) \beta \cdot t+\sigma \log \alpha
$$

The employment level depends on total output, a labour productivity trend and real labour costs. The elasticity of substitution is conventionally between zero and unity (imperfect substitution between production factors), the elasticity of employment to real labour costs is negative and lower than 1 in absolute value and the coefficient of productivity trend is negative as well. If the elasticity of substitution is equal to unity, the production function becomes a Cobb-Douglas function and labour demand has the following form: $\log L_{t}=\log Y_{t}-\log (w / p)+\log \alpha$, with a unit elasticity of real labour costs and no time trend.

There are a number of other possible equivalent ways to specify the long run condition for employment in this framework. For instance, instead of the profit maximisation problem, Fagan et al. (2001) used the employment level induced by the inverted (Cobb-Douglas) production function, which depends upon real GDP, total capital stock and trend total factor productivity. Alternatively, following the cost-minimisation problem subject to a given capital stock, employment becomes a function of real GDP, technical progress and relative factor prices. However, the choice of the profit-maximisation approach stems from the fact that real wage statistics are more reliable than capital stock data or capital cost data and available on a quarterly basis. Moreover, in this specification, employment only depends on output and labour market variables (labour costs and trend labour productivity).

In this setting, real labour cost elasticity gives a measure of the elasticity of substitution $\sigma$. In economic terms, this parameter means that a growth of $1 \%$ in the relative cost of labour to capital will lead to a growth of $\sigma \%$ in the ratio of capital to labour. More formally, we have $\sigma=$ $\mathrm{d}(\mathrm{K} / \mathrm{L}) / \mathrm{d}(\mathrm{w} / \mathrm{r}) * \mathrm{r} / \mathrm{w} * \mathrm{~L} / \mathrm{K}$, where $\mathrm{r}$ is the cost of capital. The interpretation of the time trend should also be discussed. The absolute value of its (negative) coefficient depends negatively on the elasticity of substitution $\sigma$ and positively on trend labour productivity, mirroring technology developments, assumed to be constant over time. The constant, $\sigma \cdot \log \alpha$, which turns into $\mu . \sigma \cdot \log \alpha$ with $\mu$ being the mark-up over costs in the case of imperfect competition (see Morgan, 2001), depends positively on the elasticity of substitution $\sigma$, the labour-intensity of the method of production $\alpha$ and the market power of firms $\mu$.

In this setting, the elasticity of employment to output is unity. Calling into question this result would mean to allow for the interaction between the level of labour productivity and the level of output. For instance, if we set $\log a t=\beta . t+\gamma \log Y$ with $0<\gamma<1$, the elasticity becomes less than unity. Such an interaction is difficult to explain. One could suppose that the level of output reflects the level of knowledge in the economy, as argued in some endogenous growth models. But no sound evidence has been provided on this. Therefore, in the subsequent section, we will assume an elasticity of employment to output equal to unity and use panel data analysis to test it. 


\subsection{Data used}

The euro area data for the period 1985-2002 are built from the aggregation of quarterly ESA95 National Account series. Before 1985, they have been back-cast using data of the ECB area-wide model ${ }^{5}$. Employment series refers to total employment (employees plus self-employed) in terms of persons employed. An alternative could have been to reason in terms of hours worked or full-time equivalents. This choice was motivated by two reasons. First, part-time employment data, needed to compute full-time equivalents, are missing before 1991 on a quarterly basis (Eurostat quarterly labour indicator) and are not available on an annual basis before 1983 (European Community Labour Force Survey) ${ }^{6}$. Second, compared with the number of employed persons, the estimates of hours worked are more fragile and the concept itself more uncertain (hours effectively worked or hours usually worked in the reference period). The number of persons employed is more consistent with the measures of unemployment and the labour force. However, tentative estimates based on hours worked and full-time equivalent employment will be provided in this paper as a robustness check.

Labour cost data refer to total compensation per employee deflated by euro area GDP deflator at market prices. This series encompasses total labour costs, i.e. direct (wages) and indirect (social security contribution) remuneration. However, unlike employment data, compensation per employee covers only employees' compensation, excluding remunerations of the self-employed, which are unavailable. This could slightly bias the estimation of the employment equation, because it is implicitly assumed that average compensation received by the self-employed has grown at the same pace as compensation per employee.

\subsection{Estimation method}

The explanatory variables being non-stationary, we have chosen an error-correction-model specification, allowing for distinguishing the short-term dynamics from the long-term determinants (corresponding to the cointegration relation). The use of quarterly data starting in 1970 yields a relatively long time series dimension, allowing for the precise analysis of the dynamics, which generally requires data with reasonable frequency and implies a large loss of degrees of freedom. Moreover, the relatively long period chosen covers at least three full economic cycles, which will help to better distinguish the cyclical behaviour of labour demand from possible structural changes.

From an economic point of view, the use of an error-correction model is justified by the existence of costs of adjustment, which induce a slow response to shocks to labour demand (e.g. changes in GDP or labour costs), as pointed out by the large literature on dynamic labour demand, e.g. Nickell (1986). As explained by Hamermesh and Pfann (1996), these adjustment costs are of two kinds. First, the net costs

\footnotetext{
${ }^{5}$ Data are downloadable from the ECB website. See ECB working paper no. 42, "An area-wide model (AWM) for the euro area” by G. Fagan, J. Henry and R. Mestre, January 2001.

${ }^{6}$ Other sources, for instance National Accounts, provide quarterly full-time equivalent series, which are unfortunately available for a short time period.
} 
are those of changing the numbers of employees in the firms, for instance the loss of efficiency due to the internal reorganisation of work. Gross costs of adjusting labour demand are those related to the flows of workers entering or leaving the firm, such as search and recruitment costs, slow adjustment of capital stock, the cost of training and job protection legislation (mandatory notice of layoffs, severance payment, cost of legal disputes, etc).

In order to disentangle the long-term equilibrium relation between variables and the dynamics, we will follow the two-step procedure of Engel and Granger (see Hamilton, 1994). We will estimate first the long-run level of labour demand and identify a cointegration relationship between variables. Second, an equation in first differences will be estimated to capture dynamics. In order to avoid endogeneity, the contemporaneous quarterly change in GDP and real labour costs is omitted. An estimate using instrumental variables approach, where the contemporaneous change in GDP is instrumented by lagged changes in GDP, confirms that this current term is not significant. Conversely, it turns out to be highly significant with a standard OLS approach, suggesting that the contemporary correlation between GDP and employment growth mainly captures the reverse causality, i.e. the current impact of employment to activity.

With $E, Y$ and $w / p$ standing respectively for total employment, real GDP and real labour costs, euro area labour demand can be modelled by the following equation, where $\alpha, \beta$ and $\gamma$ are estimated separately by OLS.

$\Delta \ln E_{t}=\sum_{i=1}^{I} a_{i} \Delta \ln E_{t-i}+\sum_{i=1}^{I} b_{i} \ln \Delta Y_{t-i}+\sum_{i=0}^{I} c_{i} \Delta \ln \left(\frac{w}{p}\right)_{t-i}-d\left(\ln E_{t-1}-\ln Y_{t-1}+\alpha \ln \left(\frac{w}{p}\right)_{t-1}+\beta(t-1)+\gamma\right)+e+\varepsilon_{t}$

However, this labour demand equation is estimated with actual employment data, which by definition satisfy the equilibrium condition between labour demand and the labour supply. Therefore, labour supply variables may have explained a part of the employment developments. Due to lack of data or data limitation, it appears quite difficult to control for labour supply variables in a macroeconomic equation. For instance, institutional data, constructed by Nickell and Nunziata (2001) and available at the country level, cannot be aggregated at the euro level, given the strong methodological differences in the construction of those series across countries. Moreover, the low number of observations limits the relevance of using them in a time-series approach. Another relevant supply-side dimension, the structure of population by educational attainment, cannot be taken into account, because of the lack of a long-time series. However, some demographic variables may be used to control for a part of the labour supply effects. The working age population ${ }^{7}$ appears a natural control variable positively related to employment growth, as it represents the potential labour force. Moreover, recent studies, such as Korenman and Neumark (2000) or Jimeno and Rodriguez-Palenzuela (2002) point to the importance of the age structure of the working-age population and in particular of the relative size of the youth population to explain aggregate employment and unemployment rates. Young people are most affected by labour market

\footnotetext{
${ }^{7}$ The working-age population is defined as those aged 15-64 (OECD usual definition).
} 
institutions which impose some kind of wage floor (like minimum wages, collective bargaining, employment protection legislation, unemployment benefits, etc.), which translates into a low youth employment rate compared to that of prime-age people. The increase in the relative size of the young population is supposed to decrease employment. Thus, an equation controlling for these shifts in the size and structure of the working-age population is estimated. However, as shown in equations (1) to (4) in Table 2, the effect of both demographic variables turns out to be clearly insignificant. This suggests that, given the lack of specific labour-supply-related data, actual employment developments in the euro area seem to be captured reasonably well by the standard labour demand equation ${ }^{8}$. This is highlighted by equations (1) and (2) reported in Table 3 (see also the Annex for further details regarding the estimation results).

\section{Is there any evidence of a structural change in recent years?}

This section presents some evidence pointing to a structural change in the employment behaviour in the late 1990s. First, a break is introduced in the euro area employment equation, in which the number of person employed measures employment. The role of the break and the traditional determinants is carefully assessed. Second, the robustness of the break is tested by using other measures of employment (full-time equivalent, hours worked), which permits to evaluate the importance of part-time employment developments. Lastly, the question of cross-country heterogeneity is addressed.

\subsection{Evidence of a break in the standard employment equation for the euro area}

Some evidence points to a possible change in the pattern of euro area employment in recent years. Although the overall stability of the equation is not rejected, some instability is visible at the end of the period when performing a recursive estimate of the coefficient. This may explain why the Error Correction Mechanism (ECM) term is not highly significant (see equations 1 and 2 in Table 3). Another piece of evidence is the poor performance of the dynamic simulation at the end of the period, which clearly overestimates employment in the early 1990s and underestimates it in the late 1990s (Figure 1). Dynamic contributions computed on the basis of equation 1 in Table 3 and shown in Figure 2 suggest that residuals have substantially contributed to employment growth in the period 1997-2001, explaining 0.7 p.p. of total employment growth each year on average. This is confirmed by the instability displayed by equations (1) and (2) in Table 3 from around 1997, when estimating its coefficients recursively.

\footnotetext{
${ }^{8}$ An alternative to the single equation approach would have been to estimate a system of two equations comprising a labour demand equation and a wage equation. However, such an approach would face a serious problem of identification, as all the terms of the long-run labour demand equation are also included in the long-run wage equation (see Morgan and Mourougane 2001). Indeed, by construction, the wage equation mixes labour demand aspects (firms' willingness to pay wages) and labour supply effects (employees' bargaining power). Moreover, this approach is still affected by the problem of lack of macroeconomic data on labour supply variables (skills, institutions, etc).
} 


\subsubsection{Quality of the dynamic simulation and the forecasting performance when allowing for a break}

In order to identify possible changes in employment pattern, we reestimate equation (2) (one-step ECM procedures) in Table 3 by allowing for breaks in all variables. Then we sequentially remove the least significant break until only statistically significant breaks remain. As shown in detail in Table 4, this sequential procedure leads to retaining only one break, in the intercept. According to various criteria (adjusted R square, t-value of the break, RMSE of recursive out-of-sample forecast), the break appears most relevant when starting in 1997. This is in line with the result yielded by the dynamic contribution of the residuals from the traditional equation and the recursive estimates of the coefficient. The break still appears highly significant and its magnitude is unchanged, when controlling for some observable laboursupply effects mentioned earlier (working age population and the relative size of the youth population). This emerges when comparing equations (3) and (4) in Table 2 with equation (4) in Table 3.

The break in intercept can be interpreted as the additional employment growth recorded between 1997 and 2001 which cannot be explained by traditional determinants. It corresponds to an upward shift in the long term relationship in levels, which translates into a higher but temporary employment growth rate until the new long-term level is reached, unlike a break in the trend, which would imply a permanent change in the growth rate. According to the theoretical model presented earlier in section 2, the increase in the intercept may be interpreted either as an increase in the mark-up $\mu$, which seems unlikely given the increase in competition induced by the continuing integration in the Single market ${ }^{9}$, or a rise in the labour-intensity of the method of production $\alpha$.

When including a break, the adjusted $\mathrm{R}^{2}$ from the two-step ECM estimation increases from 0.61 to 0.65 (see equations 1 and 3 in Table 3 ) and the dynamic simulations derived from either one-step or twostep estimation appear to be very close to the actual series and much better than that given by equation 1 without a break (see Figure 3). The introduction of the break makes the error correction mechanism very significant, which was not the case without a break. Each coefficient of the equation appears very stable. The long-term elasticity of real labour costs (estimated in one step) is slightly lower than that estimated in one step without the break. The strong elasticity of employment to real labour costs in equation 1 could have artificially captured the structural changes, which occurred in a period of moderate wage developments recorded since 1997.

Another illustration of the inability of traditional determinants to fully explain employment growth in the recent period is provided by the results of the out-of-sample dynamic performance. Over 3 million jobs created in the euro area since 1999 are not explained by the employment equation estimated between 1970Q1 and 1999Q1 (see Figure 4). In other words, 0.7 p.p. of the annual employment growth between 1999Q2 and 2002Q2 does not stem from the traditional determinants. More formally, the root mean squared errors (RMSEs) of the out-of-sample forecasts are one third lower when allowing for a break.

\footnotetext{
${ }^{9}$ However, the rising share of services, more protected in general from the international competition than industry, in the whole economy might have contributed to raising the aggregate mark-up, offsetting the effect of enhanced competition coming from the integration of product markets within the European Union.
} 


\subsubsection{The role of traditional determinants, when allowing for a break}

To illustrate the role of traditional determinants of employment over time, the dynamic contributions to employment growth ${ }^{10}$ are computed from equation (4) with a break (see Table 3). The results regarding the contribution of GDP or real labour costs are robust, whatever the equation considered (1), (2), (3) or (4) and are well reflected in Figure 2. For instance, they are not much affected by the inclusion of a break in the equation. Conversely, the reaction lags are very sensitive to the specification of the equation and, particularly, to the inclusion of a break.

The positive employment performance in the euro area in 1997-2001 resulted to a large extent from the robust economic growth in the second half of the 1990s (see Figure 2). Over the period 1980-2000, employment seems to have been largely driven by GDP growth. For instance, the poor employment performance in the early 1990s is clearly related to weak activity growth. Employment equations (including all the lags up to five quarters) also allow for computing the adjustment lag of employment to GDP over different sub-periods. As shown in Table 5, in the period 1970-2002, employment growth is found to react to GDP with a mean lag of around eight quarters, when we estimate the equation with all lags. The mean lag seems to have decreased in the late 1980s-early 1990s and increased in the recent period. However, when we use an alternative equation, retaining the significant lags only, these results are reversed and the mean lag of GDP between 1985 and 2002 shortens somewhat down to 6 quarters, which leads us to interpret the mean lag with considerable caution. Conversely, the median (50\% of the longterm effect) reaction lag to GDP seems to have been fairly stable over the past thirty years, at around 4.5 quarters. On the whole, reaction lags tend not to signal any noticeable change in the adjustment process of employment to GDP.

As shown by Figure 2, the deceleration of real labour cost growth between 1992 and 1996 set the conditions for dynamic employment growth. By contrast with the late 1980s, real labour cost developments remained moderate during the last upturn of 1997-2000, contributing partly to the historically strong employment expansion. If real labour cost developments had been the same as those recorded in the late 1980s, annual employment growth would have been 0.3-0.4 percentage point lower than actually seen since mid-1997. Although most of the slowdown in employment growth is attributable to the economic downturn, the slight increase in real labour costs since mid-2000 seems to have adversely affected employment growth in 2001 and the first half of 2002. Likewise, the poor employment performance in the early 1990s, mainly related to the slowdown in activity, was worsened by the strong labour cost increase. The slow employment growth recorded in the late 1970s despite buoyant economic growth was also likely linked to the substantial increase in real labour costs seen in this period. The various economic equations estimated here suggest that the mean lag of employment to real labour cost developments between 1985 and early 2002 was around 5 quarters and the median lag between 3 and 5

\footnotetext{
${ }^{10}$ These contributions are computed other things remaining equal, i.e. supposing that the exogenous variables in the model are not interdependent. For instance, any rise in output would lead to higher employment and then lower unemployment, and thus, higher real wages, according to the Philips Curve. The rise in real labour costs would partly offset the initial effect of higher output on employment.
} 
quarters (see Table 6). Moreover, it seems that the mean and median reaction lags of employment to labour cost have not changed significantly since 1997.

\subsection{Robustness of the break while considering hours worked or employment in full-time equivalents}

Evidence of a structural break in employment behaviour suggests that employment developments could also have been affected by labour market reforms or structural changes (in addition to the indirect effect passing through labour cost moderation, such as the social security contribution cuts). A natural candidate to explain the lower trend productivity in the late 1990s is the rising share of part-time in total employment, meaning that an increasing proportion of those employed is working less. This development has caused a reduction of hours worked per person of 0.25 p.p. per year on average between 1997 and 2001, according to Labour Force Survey data. As this effect combined with possible measurement effects $^{11}$ may explain around 0.3 p.p. out of 0.7 p.p. unexplained by traditional determinants ${ }^{12}$, other structural changes or labour market reforms should have played a role in explaining the remaining 0.4 p.p. in the change in employment behaviour. Moreover, the timing of part-time employment developments indicates that they are unlikely to account for a break in employment in the late 1990s. Indeed, the positive contribution of part-time jobs to total employment growth declined from the late 1990s, as shown by the reduced difference between employment growth measured in number of persons and in full-time equivalents (see Figure 5). The difference between employment growth measured in number of persons and in full-time equivalents, which was around 0.4 p.p. on average between 1991 and 1998, fell to around 0.1 p.p. between 1999 and $2001^{13}$. Looking further back, part-time employment developments and their contribution to total employment growth were broadly similar to those recorded in the late 1980s, when economic growth was much less job-intensive.

To underpin this result, the equation with break (equation 3 in Table 3) is re-estimated with employment in terms of full-time equivalents (see Table 7). While the error correction mechanism appears much less significant, the break in intercept is still significant at 5\%. The break is of a lower magnitude than in the equation estimated with employment in terms of persons: around 0.3 p.p. annual employment growth in full-time equivalents has not been explained by traditional determinants between 1997 and 2001. Of course, this lower part of unexplained employment growth after 1997 reflects the effect of part-time on recent employment growth. This result is broadly consistent with those found by Garibaldi and Mauro (2002): increases in part-time employment in the services sector, where most part-

11 The employment performance may also have been affected by the change in employment definition in Germany (measurement effect). The inclusion of low-paid part-time jobs in the new employment definition in Germany might have increased euro area employment growth by around +0.1 p.p. year-on-year in 1997-2001. Indeed, these low-paid part-time jobs were not included in employment data in the past, while this category of workers grew at a very fast pace. However, the magnitude of this effect should be considered with considerable caution.

${ }^{12}$ Measured as the average contribution of the residual in the equation without break over the period 1997-2001 (column 1 in Table 3).

${ }^{13}$ While the decrease in the contribution of part-time work to net job creation was, of course, mainly accounted for by the slower increase in the part-time employment rate (by around 2 p.p.), the relative increase in hours worked in part-time in 19992001 played an additional role (by around 0.5 p.p.). The latter effect is, however, relatively weak and seems to go in the same direction as the development in the part-time rate. 
time jobs were created, have been associated with increases in the overall number of jobs but most likely also with partial crowding out of full-time jobs.

The use of full-time equivalents improves the measure of "effective" labour but does not take into account developments in usual hours worked by full-time workers as well as changes in the number of working days. Thus, the equation with break has also been re-estimated with employment in terms of total hours worked (see Table 7). The series was built by Korteweg and Vijselaar (2002), using OECD data on total hours worked in the economy, completed by Labour Force Surveys data on usual weekly working hours. A positive break from 1997 onwards is significant at the 1\% level and corresponds to a 0.4 p.p. unexplained annual growth in hours worked in the period 1997-2001. This latter result should be taken with caution, given the fragility of working time measurements, but confirms the break in employment behaviour at the end of the period.

\subsection{Taking account of heterogeneity across countries}

In order to infer that employment behaviour has changed in recent years, it is necessary to check if the break for the euro area as a whole is broadly based across countries or if this only reflects specific features in a very limited number of countries. In addition, the findings presented for the euro area as a whole might be slightly affected by an aggregation bias, due for instance to changes in country weights over time. For this purpose, fixed-effects regressions are run with a macro-panel of 21 OECD countries. A break in employment equation, modelled as a dummy for the period 1997-2001, is tested for the EU countries and euro area countries (see Table 8). As shown in columns 1 and 2, the break for these two groups of countries appears fairly low and insignificant. The break for countries outside the euro area and the EU turns out to be negative and clearly insignificant.

As shown in Table 9, regressions allowing for a break for each euro area country seem to indicate that a group of countries (Belgium, France, Ireland, Italy, the Netherlands and Spain) have recorded a stronger employment growth that is not fully explained by classical determinants. Indeed, the break in these countries appears significant in all regressions (except for Ireland). It should also be noted that the significance of the break is not strongly affected by the choice of its starting date. Although its exact dating is somehow arbitrary, we make the break start from 1997 onwards in order to be consistent with results for the euro area shown in section 3.1. This choice is broadly supported by country-by-country estimates ${ }^{14}$. The break turns out to be particularly significant for Spain and France. Additional growth recorded in these countries since 1997 varies from 0.9 percentage point in Belgium to 3.6 percentage points in Spain. Conversely, the second group of countries (Austria, Finland, Germany, Greece and Portugal) has not experienced any clear change in their employment pattern. In other words, in these countries, employment growth was mostly explained by the traditional determinants in the recent years.

\footnotetext{
${ }^{14}$ In addition to the panel approach, we also re-estimated equations (1) and (2) presented in Table 9 country by country so as to allow for different starting dates for the break. The results for equation 2 are presented between brackets. The statistical significance of the break is maximised when it starts in 1998 (1998) for Belgium, in 1995 (1995) for Spain, in 1998 (1998) for France, in 1994 (1996) for Ireland, in 1998 (1999) for Italy and in 1997 (1995) for the Netherlands. However, the magnitude and the significance of the break are not dramatically affected when we make it start in 1997 for all countries.
} 
For most OECD countries outside the euro area, the break is insignificant, with the exception of Japan, where it is negative. The regression in column 4 of Table 8 summarises these results by testing the break globally for both groups. In the first group, accounting for around 59\% of the total euro area employment, more than 0.7 p.p. employment growth has not been explained by traditional determinants since 1997, this break being statistically significant. The break is negative but clearly insignificant in the second group of countries ${ }^{15}$. These results confirm that most euro area countries have experienced positive structural changes but not all of them.

\section{What factors may account for a change in aggregate employment pattern in recent years?}

This section enters a very difficult area, trying to explain the change in employment pattern, shown empirically in the previous section. Three aspects are investigated in this section: changes in the sectoral composition of the euro area employment, developments in labour market institutions and the impact of active labour market policies.

\subsection{Changes in the sectoral composition of euro area employment}

Compositional effect may have played a part in explaining development in aggregate employment growth, as suggested by Marimon and Zilibotti (1998). A simple accounting exercise indicates that the average annual growth rate of employment between 1997-2001 would have been around 0.2 percentage point lower if the sectoral composition of employment had remained the same as in 1986-1991 (see Table 10). Indeed, the share of sectors with high employment growth (i.e. market-related services, such as trade, repairs and financial and business services) was much higher at the start of the economic expansion of the late 1990s than at the beginning of the boom of the late 1980s. Those sectors are characterised by a strong economic growth, high employment intensity or both. The strong employment growth in market-related services is broadly attributable to a very strong value-added growth. Job intensity of growth, measured by the ratio of employment to value-added growth, appears to have been very high (1.4) in financial, real estate renting and business services in 1997-2001, while it was higher in trade, repairs, hotels and restaurant, transport and communication than in industry excluding construction.

Symmetrically, sectors with low or negative employment growth (such as agriculture and industry excluding construction) had a lower weight in total employment in the late 1990s than in the previous decade. Given that, as a first approximation, total employment growth can be computed as the sum of sectors' employment growth weighted by the share of each sector in total employment, the movements in the sectors' share might affect total growth even though there is no change in sectoral growth. Another way to consider the compositional effect is to notice that employment growth in all sectors (except

\footnotetext{
${ }^{15}$ A similar equation has been estimated for the EU (see column 3), leading to the same conclusion.
} 
agriculture) was lower in the period 1996-2001 than in 1986-1991, while aggregate employment growth was broadly similar, as seen in Table 10 .

\subsection{The importance of labour market institutions}

It was found earlier that part-time development contributed to higher employment growth in the 1990s but cannot fully explain the break in the late 1990s. The evidence of the effect of structural reforms on macroeconomic labour market variables appears patchy in the literature, mainly due to the difficulty to quantify and study labour market reforms at a macro-level. Moreover, most of the labour market institution data used in this section are not available for the late 1990s. Thus, the goal of this section will remain modest, attempting to collect first quantitative evidence by introducing labour market variables in employment equations. While past studies mainly focused on unemployment, this section emphasises the effect of labour market institutions on net employment creation.

Table 11 shows the panel data estimates of employment models when including annual data on labour market institutions as collected from various sources by the OECD and Nickell and Nunziata $(2001)^{16}$. Two sets of institutions should be distinguished: those influencing both labour demand and labour supply (job protection legislation ${ }^{17}$, total taxes on labour, unionisation ${ }^{18}$ and wage bargaining coordination) and those mostly affecting labour supply (benefit replacement rates and benefit durations). Various estimations have been carried out. Regression (1) uses the first group of institutions, while regressions (2) to (8) also integrated the second group of institutions. Following the approach of Belot and van Ours (2000), interactions between institutions are taken into account in regressions (4) and (6). Such interactions are used as a robustness check and take into account the fact that similar reforms could have different effects in different countries and comprehensive reforms are more effective than piecemeal labour market policy ${ }^{19}$.

The equations estimated follow two slightly different specifications. Equations (1) to (4) correspond to the traditional employment equation, estimated in section 2 for the euro area as a whole. They use total employment (in logarithm) as the dependent variable and include also the GDP level and real labour costs. Thus, the following general specification is estimated, where $E$ denotes employment (either in $\log$ or in rate), Y real GDP and w/p real labour costs (compensation per employee deflated by the GDP deflator), the $i$ and $t$ are country- and time- indices and $k$ kinds of institutions $X_{k}$ are taken into account and interact with each other:

$$
\ln E_{t i}=\alpha_{i}+\alpha_{t}+\beta \ln Y_{t i}+\gamma \ln \frac{\mathrm{w}}{\mathrm{p}_{t i}}+\sum_{k=1}^{K} a_{k} X_{k t i}+\sum_{k}^{K} \sum_{j \neq k}^{J} b_{k j} X_{k t i} X_{j t i}+\varepsilon_{t i}
$$

\footnotetext{
${ }^{16}$ For the most recent observations, see also S. Nickell, L. Nunziata and W. Ochel "Unemployment in the OECD since the 1960s. What do we know?" Bank of England, May 2002. outsiders.

${ }^{17}$ Indeed, EPL can raise insider power and therefore lower effective labour supply by reducing the wages expected by

${ }^{18}$ Called also union density. This is the percentage of reported union members among wage and salaried employees.

${ }^{19}$ From an econometric point of view, this is referred to as semi-poolable time series.
} 
Equations (5) and (6) refer to the specification used by Nickell et al. (2001), in which the dependent variable is the employment rate (i.e. the ratio of total employment to population aged 15-64) and GDP and real labour costs are replaced by country trends.

All the equations are estimated over a sample of euro area countries, as the test for poolability suggests that the effect of explanatory variables is very different between euro area countries and the other OECD countries. Indeed, a Chow test strongly rejects the hypothesis of common slopes across these two groups. A possible and tentative explanation may be that the effect of institutions is stronger in countries facing significant rigidities in their labour market, which seems to be the case for most euro area countries. Therefore, the equations shown in Table 11 are estimated on a panel of euro area countries only. However, the results in terms of sign and significance are not very different when including other OECD countries in the sample. Moreover, as shown by Nunziata for the institutions (2001), there is clear evidence of non stationarity for many of the variables used in the equations. We therefore need to test for cointegration so as to check the absence of spurious regressions. The Madala-Wu test consists in testing for unit roots in the residuals of the equations ${ }^{20}$. The test clearly rejected the hypothesis of residuals having a unit root.

Several findings should be emphasised. First, the total labour tax rates ${ }^{21}$ (called also tax wedge, i.e. employees' and employers' social security contributions and personal income tax as percentage of total labour costs) appears to be significant in all equations. Its coefficient is always negative and relatively stable, at around -0.15 . Given the autoregressive term, this means that, other things being equal, a decline of 10 percentage points in the total labour tax rate would lead in the long run to a rise of around $11 \%$ in the level of employment (models 1 to 3 ) or to 7 percentage point increase in the employment rate (model 5), which represents a fairly strong effect. Moreover, total labour taxes have an additional adverse effect when combined with a high union density.

Second, evidence appears mixed for employment protection legislation (EPL). It is found to be negatively correlated to employment in all equations without interactions. However, it only appears significant in models (1) to (3). When adding interaction between institutions, the effect of employment protection legislation on its own becomes negative. Nonetheless, it has a negative impact on employment when combined with the level of bargaining co-ordination (model 4) or unemployment benefit duration (model 6). The latter institutions are likely to raise the bargaining power of insiders and then the equilibrium wage, which lowers effective labour supply by reducing the prospect of the "outsiders" of being hired. EPL may exacerbate this phenomenon of labour supply segmentation by limiting further the ability of outsiders to compete with insiders.

\footnotetext{
${ }^{20}$ As the test relies on the assumption of no cross-country correlation, we control for cross-country correlation by means of time dummies in the equation.

${ }^{21}$ This indicator is an average macroeconomic measure computed from national account data. This average tax wedge can also be seen as the difference between the after-tax disposable labour income received by wage earners and total labour costs borne by employers.
} 
Third, the level of bargaining coordination is found to be positively correlated with employment. While it appears strongly significant (at a level of 1\%) in models (4) and (6), it is not significant in the other equations. Model (3) permits to reject the hypothesis of the convexity ${ }^{22}$ in the effect of bargaining coordination, as modelled by the square of bargaining co-ordination variable. This is supported by the economic literature (e.g. Nickell et al., 2001), which found that highly co-ordinated bargaining offset the adverse effects of unionisation on employment.

Fourth, apart from some interactions with the tax wedge or EPL, unionisation, the unemployment benefits replacement ratio and unemployment benefit duration are found not significant in general (or displaying an unexpected sign in equation 6). Although the unemployment benefits replacement ratio seems to adversely affect the employment rate, it has no impact on total employment and the effect is not robust to the introduction of interactions.

Five, equations (4) and (6) confirm that institutions play a role, not only in isolation but also interacting between each other. However, the significance of these interactions does not appear robust to the specification chosen (logarithm of total employment versus employment rate), except for the joint negative effect of total labour taxes and unionisation.

The interpretation of the findings requires much caution, as some results are not robust across the various models estimated. Indeed, the small number of time varying observations for institutions as well as high collinearity among institutional variables does not permit to identify precisely the impact of individual institutions. Moreover, the role of some institutional variables such as taxation and employment protection in determining employment has extensively been discussed in both the theoretical and empirical literature and appears not to be clear cut. However, Daveri and Tabellini (2000) show that higher taxes lead to higher unemployment and lower output growth. An increase in labour taxation is likely to raise total labour costs, leading to lower employment growth. The econometric results shown in Table 11 go in this direction. In some countries, labour tax rates are unevenly distributed among wage earners, being particularly high for low wage earners, youth or low-skilled workers, therefore reducing further their employability. Hiring the low skilled is all the more costly for employers as employment protection limits the possibility of firing workers who turn out to display low productivity.

The impact of employment protection legislation on employment appears ambiguous. Bentolila and Bertola (1990) argue that both job creation and destruction will decrease as a result of an increase in labour adjustment costs but the resulting effect on total employment in the long run is uncertain. Bertola (1992) suggests also that individual sectors may be affected differently by job protection, which complicates the analysis at the aggregate level. However, Caballero and Hammour (1998) have highlighted that a rise in firing costs may lead firms to substitute capital for labour in the medium run, resulting in a lower job intensity of economic growth. Empirically, the evidence is mixed. Using crosssectional data, Nickell (1997) and Nickell et al. (2001) do not find a significant effect of employment

\footnotetext{
22 This corresponds to the hypothesis of "U-shaped curve", presented by Calmfor and Driffil (1988): very decentralised or, at the other extreme, very centralised wage bargaining structure would lead to a better outcome in terms of unemployment and employment than the intermediate case of negotiation by branch.
} 
protection legislation on unemployment rates and employment rates across countries, whereas Blanchard and Wolfers (2000) argue that higher employment protection leads to a larger effect of adverse macroeconomic shocks on unemployment. Exploiting time-series dimension of the data, Lazear (1990) and Scarpetta (1996) show a positive relationship between firing costs and unemployment, while Morgan (2001) finds that employment security slows the dynamic adjustment of employment but does not increase the number of persons employed.

\subsection{The role of active labour market policies}

In addition to the institutions mentioned above, active labour market policies (ALMP) may have played a role in explaining the good employment performance in the late 1990s. Table 12 presents panel data estimates using OECD data (database on labour market programmes). In order to take into account that active labour market measures are likely to impact employment growth gradually and to correct for endogeneity problems ${ }^{23}$, ALMP are computed as the share of ALMP expenditures in GDP lagged by two years. The results are based on a euro area panel, but for most models they are found broadly similar between euro area countries and other OECD countries, according to a Chow test on common slopes.

The findings are mixed in the sense that none of the ALMP expenditures appears statistically very significant. However, it should also be noted that coefficient signs are consistent across models (1), (2), (3) and (4), except for public employment training. Model (1) shows that expenditures devoted to public employment services, labour market training and subsidised employment are not significant (at a 5\% level). In model (2), subsidies to employment have been broken down into subsidies to regular employment in the private sector and direct job creation in the public sector. The former, which comes down to lowering taxation rates and reducing labour costs, is positively correlated with employment growth, although not statistically significant. Direct job creation in the public or non-profit sector does not seem to affect future employment growth with a very low coefficient and $t$-statistic. In a recent study, Algan et al. (2002) argue that job creation in the public sector crowds out private sector employment and can even eventually lead to a decline in total employment. The attraction for public activities (positively depending on the size of rent in the public sector and the degree of substitutability of public and private jobs) exerts upward wage pressure in the private sector, reducing employment in this sector. Moreover, direct job creation might contribute to increase taxes, which have distorting effects on economic activity. In model (3), expenditures for youth have been included but are not significant at all. Their sign is not the one expected. Model (4) is a re-estimation of model (2) using the employment rate instead of the natural logarithm of total employment. Subsidies to regular employment in the private sector turn out to be significant at $10 \%$ level, while the $t$-statistic for direct job creation is close to zero.

All in all, the results based on aggregate data are not very robust and display a low level of statistical significance. Scarpetta (1996) confirms that some ALMP, such as job assistance, training programs and

\footnotetext{
${ }^{23}$ It is indeed difficult to identify the causal relationship between employment and ALMP. Sluggishness in the labour market induces mechanically an increase in ALMP, as more people become eligible. On the other hand, a high level of ALMP may improve the employment prospects of the unemployed and increase employment.
} 
financial assistance for firm creation can stimulate employment. Nevertheless, Layard, Nickell and Jackman (1991) emphasise that the composition of spending is as important as the level. Moreover, as pointed out by Decressin et al (2001), ALMP tend to be ineffective when they are not focused on welldefined beneficiaries. For example, broadly based employment subsidies may have little effect relative to the level of expenditures because of dead-weight losses or substitution effects detrimental to nonsubsidised employment. Using country evidence, Decressin et al. (2001) conclude that the increased employment intensity of growth is unlikely to have primarily been caused by ALMP. However, the increase in subsidies to regular employment in the euro area private sector, which doubled as a percentage of GDP from 1994 to 2000, might have contributed to the positive employment performance. This argument is close to that stated earlier about the reduction in labour taxes in the euro area. Employment in public administration increased relatively slowly in the late 1990s compared with that in other sectors, which may also have supported employment creation in the private sector (see Algan et al., 2002).

\subsection{The role of structural changes in explaining cross-country differences in recent employment performance}

The role of structural changes may be highlighted further by relating the cross-country differences observed in the employment pattern since 1997 to changes recorded in the sectoral composition of employment, institutions and active labour market policies in the second half of the 1990s. As mentioned earlier in section 3.3, some countries (Austria, Germany, Greece, Finland and Portugal) do not seem to have experienced any significant change in their aggregate employment pattern, while the others benefit from higher than expected employment in the recent period.

Looking at the observed cross-country differences and as shown by Figures $6 \mathrm{a}, 6 \mathrm{~b}$ and $6 \mathrm{c}$, a clear negative relationship emerges between labour tax rates and the presence of a positive break in recent employment performance, confirming the panel results presented in section 4.2. In particular, countries with higher than expected employment in the late 1990s experienced a decline (Ireland, Netherlands, Spain) or at least no movement in their labour tax rate (Belgium and France), while most of the countries which saw no significant change in their employment growth in the late 1990s faced an increase in their tax wedge. One should also notice that the countries experiencing a rise in the tax wedge did not face lower than expected employment owing perhaps to an offsetting effect of the concomitant loosening in their employment protection legislation. Looking deeper into tax reforms, while there have been acrossthe-board tax-cutting measures in most euro area countries in recent years, some particular attention has been paid to reducing tax pressure at the lower end and in the middle of the income distribution (see also ECB 2002b). The strong decline in tax rates on low-wage earners recorded in the late 1990s (by 3 p.p.), which was mainly related to cuts in employers' social security contribution, is indeed a natural candidate to account for the strong employment performance in this period.

Although the other variables are less tightly linked to the presence of a positive break in employment pattern, some interesting results have been found. The cross-country analysis confirms that the impact of changes in the sectoral composition of employment is positively correlated to employment performance, 
but to a much lesser extent than tax wedge. In particular, it may have contributed to explaining the break in employment seen in particular in France, Italy, Ireland and Spain (see Figure 6a). The strong decline in employment protection legislation in Belgium, Italy and Spain may also partly explain the good employment performance recorded in these countries. In line with the results found in section 4.3, Table $6 c$ suggests that subsidies to regular employment in the private sector may also have helped in improving employment performance in the late 1990s in Belgium, France, Italy and the Netherlands. Conversely, Austria, Germany, Greece and Portugal may have suffered from a decline in the rate of subsidies to private sector employment. Lastly, Belgium, Ireland, the Netherlands and, to a lower extent, Italy may have benefited from the strong rise in the part-time employment rate, whereas Greece and Finland suffered from relatively weak developments in part-time employment. However, the role of part-time job developments in accounting for cross-country differences in employment performance does not appear predominant as Germany, and to a lesser extent Portugal and Austria, also experienced a significant rise in the part-time employment rate.

Conversely, other institution such as the share of temporary jobs, union density, benefit replacement rate, benefit duration or most ALMP (public employment services, labour market training and direct job creation in the public sector) do not display any evident clear link with the employment performance in euro area countries in the late 1990s. This is again broadly in line with panel data findings reported earlier. However and more tentatively, it is plausible that Germany and Portugal may have suffered from the strong concomitant increase in the replacement rate and the duration of unemployment benefit. At the other extreme, Spain which experienced the strongest break in the employment performance may have taken advantage of the decline in benefit replacement rate and union density in addition to that in employment protection legislation and tax wedges.

To summarise, tentative evidence seems to point to the positive impact of structural changes on employment creation. However, the timing of the structural break (from 1997-1998 onwards according to panel data and time series estimates) is important. The IMF (1999) argues that it is not a coincidence that positive effects of structural reforms appear in economic upturns, even though the reforms were implemented earlier. This argument is similar to that developed by Blanchard and Wolfers (2000), according to whom a labour market outcome results from the interaction of both macroeconomic shocks and institutions. The increase in "potential employment", induced by structural changes and reflected by higher job intensity, will raise potential output, which will require a corresponding increase in effective demand so that reforms could translate into effective increases in output and employment. Furthermore, following a rationale close to Rowthorn's (1999), an increase in capital stock, which is mainly driven by the cycle, may also be required for the positive effects of structural reforms to actually lead to create new jobs. An alternative (and not mutually exclusive) explanation for the timing of the impact of labour market reforms may be that many of them have been taken in the mid-1990s and may have materialised gradually over the late 1990s (see ECB 2002a). 


\section{Conclusion}

The present paper aims to better understand the recent employment growth in the euro area. Econometric estimations of labour demand show that employment growth inertia coupled with a productivity trend and the lagged impact of both economic growth and real labour costs can largely explain employment developments between 1970 and the mid-1990s. Moreover, relatively low increases in real labour costs in the late 1990s compared to the 1980s certainly contributed to the good employment performance recorded in recent years. However, employment equations estimated for the period 19701996 explain only partly the strong employment growth observed between 1997 and 2001. The inclusion of a break from 1997 onwards improves substantially the fit of the dynamic simulation. The significance of the break seems robust, whatever the measure of employment used (employment per head, full-time equivalents or hours worked). Moreover, most euro area countries (but not all) appear to have experienced a break in the late 1990s.

Compositional effects, linked to the higher share of fast growing and job-intensive sectors such as market related services in total employment in the late 1990s, is likely to have slightly raised aggregate employment growth in recent years. Albeit difficult to show clearly, the break in employment would also suggest that labour market reforms and/or structural changes might have played a role in the good employment performance in the euro area $^{24}$. The strong development of part-time jobs in the 1990s should have played a positive part and lower labour tax rates should have contributed to the good employment performance since 1997 in the euro area. More tentatively, the relaxation of job protection legislation may have facilitated employment creation in the late 1990s. Furthermore, some active labour market policies, such as subsidies to private employment, might also have played a positive role, although the results do not appear very significant or robust. Conversely, most ALMP are found clearly insignificant in explaining employment developments. It should be borne in mind that data limitations, particularly for labour market institutions (poor time series dimension and unavailability of very recent data) and active labour market policies (highly aggregated data), as well as the lack of robustness of some results call for considerable caution in explaining the break in employment. The results presented in the last section on the impact of institutions and active labour market policies illustrate the difficulty of highlighting the effect of structural reforms at a macroeconomic level, as confirmed by numerous studies.

\footnotetext{
${ }^{24}$ It should be noted that the compositional effects and the impact of institutions are not mutually exclusive, as structural reforms may also boost service sector growth.
} 


\section{References}

Algan Y., P. Cahuc and A. Zylberberg (2002), "Public employment. Does it increase unemployment?" ", Economic Policy, April.

Arrow, K., H. Chenery, B. Minhas and R. Solow (1961), "Capital-labour substitution and economic efficiency", Review of Economics and Satistics, vol 43, pp. 225-250.

Baltagi, B. (1995), Econometrics of panel data, Wiley, West Sussex.

Belot, M. and J. van Ours (2000) "Does the recent success of some OECD countries in lowering their unemployment rates lie in the clever design of their labour market reforms?", CEPR Discussion Paper No. 2492.

Bentolila, S. and Bertola, G. (1990) "Firing costs and labour demand: how bad is eurosclerosis?", Review of Economic Studies, 57, 381-420.

Bertola, G. (1992) “Labour Turnover Costs and Average Labour Demand," Journal of Labor Economics, $10,389-411$.

Bertola, G., F.D. Blau and L.M. Kahm (2002) "Comparative analysis of labour market outcomes; Lessons for the US from the international long run evidence", in A. Krueger and R. Solow, eds. The Roaring Nineties: Can full employment be sustained?, New York: Russell Sage.

Blanchard, O. and J. Wolfers (2000) "The Role of Shocks and Institutions in the Rise of European Unemployment: the Aggregate Evidence”, Economic Journal Vol. 78(2), pp.182-187.

Brown, R.L., J. Durbin and J.M. Evans (1975) "Techniques for testing the constancy of regression relationships over time”, Journal of the Royal statistical society, n², pp 149-192.

Caballero, R. and M. Hammour (1998). "Jobless growth: Appropriability, factor substitution and unemployment”, Carnegie-Rochester Conference Series on Public Policy, 48, 51-99

Calmfors, L. and J. Driffill (1988) "Bargaining Structure, Corporatism and Macroeconomic Performance", Economic Policy, April.

Daveri, F. and G. Tabellini (2000) "Unemployment, Growth and Taxation in Industrial Countries", Economic Policy, April.

Decressin, J., M. Estevão, P. Gerson and C. Klingen (20001). "Job-rich growth in Europe”. Chapter 3 in "Selected Euro-Area Countries: Rules-Based Fiscal Policy and Job-Rich Growth in France, Germany, Italy and Spain", Country Report No. 01/203, IMF.

Duchêne, S. and A. Jacquot (1999), "Une croissance plus riche en emplois depuis le début de la décennie? Une analyse en comparaison internationale", Document de travail de l'INSEE, G9901, Février.

ECB (2002a), "The composition of employment growth in the euro area in recent years", ECB Monthly Bulletin, November. 
ECB (2002b), "Labour market mismatches in euro area countries", report prepared by the Monetary Policy Committee of the European System of Central Banks, March.

Escriban A. and G. A. Pfann (1998), "Non linear error correction, asymmetric adjustment costs and cointegration" Economic Modelling, 15, 197-216

European Commision (2000), "Performance of the European union Labour Market", European Economy, No 4.

Fagan, G., J. Henry and R. Mestre, "An Area-Wide Model (AWM) for the Euro Area", ECB working paper series, No. 42, January.

Garibaldi P. and P. Mauro (2002), "Employment growth. Accounting for the facts", Economic Policy, April.

Hamermesh D. and G.A. Pfann (1996), "Adjustment costs in factor demand", Journal of Economic Literature Vol. XXXIV, pp. 1264-1292.

Hamilton, J.D. (1994), Time series analysis, Princeton University Press.

IMF (1999), "Chronic unemployment in the Euro Area: Causes and Cures", World Economic Outlook, May.

Jackman, R., C. Pissarides and S. Savouri (1990), “Unemployment Policies”, Economic Policy, October.

Jackman, R., S. Roper (1987), "Structural Unemployment", Oxford Bulletin of Economics and Statistics, 49,1 .

Korenman, S. and D. Neumark (2000), "Cohort crowding and youth labor markets: a cross-national analysis." In D. Blanchflower and R. Freeman, eds. Youth employment and joblessness in advanced countries, NBER, Chicago University Press.

Korteweg, G. and F.W. Vijselaar (2002), "A Tale of Eight Legs on a Fly“, paper prepared for the annual conference of the International Association for Official Statistics, available at http://www.statistics.gov.uk/IAOSlondon2002/

Layard, R., Nickell, S. and Jackman, R. (1991), "Unemployment, macroeconomic performance and the labour market", Oxford University Press, Oxford.

Lazear, E. P. (1990) “Job Security Provisions and Employment”, Quarterly Journal of Economics 105.

Marimon, R. and M. Zilibotti (1998), “Actual versus virtual employment in Europe: Is Spain different?”, European Economic Review, 42(1).

Mermet, E. (2001), "Wage Formation in Europe”, ETUI, Brussels.

Morgan, J. (2001), "The employment security and the demand for labour in Europe", Applied Economics, 33, 1763-1774.

Morgan, J. and A. Mourougane (2001), "What can changes in structural factors tell us about unemployment in Europe”, ECB working paper series, No. 81, October. 
Nickell S. (1986), "Dynamic models of labour demand", in Handbook of Labour Economics, volume 1, Edited by O. Ashenfelter and R. Layard, Elsevier Science Publishers, 473-522.

Nickell, S. (1997), Unemployment and labour market rigidities: Europe versus North America, Journal of Economic Perspectives 11(3), 55-74.

Nickell, S. (1998), Unemployment: question and some answers, The Economic Journal, 108 (May), 802816.

Nickell, S and L. Nunziata (2000), "Employment patterns in OECD countries," CEP Discussion Papers 448, Centre for Economic Performance, LSE

Nickell, S, L. Nunziata, W. Ochel and G. Quintini (2001), "The Beveridge Curve, Unemployment and Wages in the OECD from the 1960s to the 1990s - Preliminary Version," CEP Discussion Papers 502, Centre for Economic Performance, LSE.

Nickell, S and L. Nunziata (2001). Labour Market Institutions Database. Centre for Economic Performance, LSE.

Nickell, S, L. Nunziata and W. Ochel (2002), "Unemployment in the OECD since the 1960s. What do we know?" Bank of England, May.

Nunziata, L (2001). Institutions and Wage Determination: a Multi-Country Approach. Nuffield College Working Papers in Economics, (2001-W29), December.

OECD (1994), The Jobs Study, Paris.

OECD (1997), Employment Outlook, Paris.

OECD (1999), Employment Outlook, Paris.

Pichelmann, K. (2001), “Wage discipline in EMU. A Feature of the Early Years. Only?", paper prepared for the $3^{\text {rd }}$ ECB Labour Market Workshop, 10-11 December 2001. "How are wages determined in Europe?".

Rowthorn, R. (1999), “Unemployment. Capital-Labor Substitution and Economic Growth”, IMF Working Paper series No. 99/43, March 1, 1999

Scarpetta, S. (1996), "Assessing the role of labour market policies and institutional settings on unemployment: A cross-country study", OECD Economic Studies 2(26), 43-82. 


\section{FIGURES AND TABLES}

Table 1

Employment, activity and job intensity during economic expansions

\begin{tabular}{|l|cccc|}
\multicolumn{5}{|c|}{ Average annual change \%, unless otherwise indicated) } \\
\hline \multicolumn{5}{|c|}{ Period of economic expansion } \\
\hline Euro area & $1969-1973$ & $1976-1980$ & $1986-1990$ & $1997-2000$ \\
total employment & 0.8 & 0.4 & 1.4 & 1.6 \\
GDP & 5.3 & 3.3 & 3.3 & 2.8 \\
ratio employment growth / GDP & $\mathbf{0 . 2}$ & $\mathbf{0 . 1}$ & $\mathbf{0 . 4}$ & $\mathbf{0 . 6}$ \\
\hline growth & & & & \\
United Kingdom & 0.3 & 0.1 & 1.9 & 1.4 \\
total employment & 2.6 & 1.8 & 3.3 & 2.9 \\
GDP & $\mathbf{0 . 1}$ & $\mathbf{0 . 1}$ & $\mathbf{0 . 6}$ & $\mathbf{0 . 5}$ \\
ratio employment growth / GDP \\
growth & & & & \\
US & 1.6 & 3.0 & 2.1 & 1.6 \\
total employment & 2.9 & 3.7 & 3.2 & 4.2 \\
GDP & $\mathbf{0 . 5}$ & $\mathbf{0 . 8}$ & $\mathbf{0 . 6}$ & $\mathbf{0 . 4}$ \\
\hline $\begin{array}{l}\text { ratio employment growth / GDP } \\
\text { growth }\end{array}$ & & & & \\
\hline
\end{tabular}

Sources: European Commission, Eurostat, OECD and author's calculations. 
Table 2

OLS Estimates of employment equations, controlling for some labour supply effects (age structure and working age population).

\begin{tabular}{|c|c|c|c|c|}
\hline & $\begin{array}{l}\text { Equation (1) } \\
\text { without break } \\
\text { (one step- } \\
\text { estimation) }\end{array}$ & $\begin{array}{l}\text { Equation (2) } \\
\text { Without break } \\
\text { (one step- } \\
\text { estimation) }\end{array}$ & $\begin{array}{l}\text { Equation (3) } \\
\text { without break } \\
\text { (one step- }^{(1)} \\
\text { estimation) }\end{array}$ & $\begin{array}{l}\text { Equation (4) } \\
\text { without break } \\
\text { (one step- }^{(1)} \\
\text { estimation) }\end{array}$ \\
\hline Estimation period & 1970Q1-2002Q2 & 1970Q1-2002Q2 & 1970Q1-2002Q2 & 1970Q1-2002Q2 \\
\hline 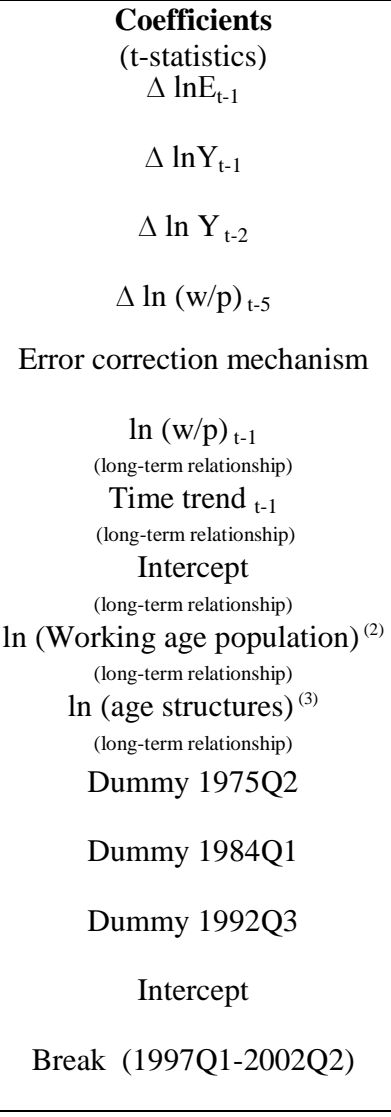 & $\begin{array}{c}0.39 \\
(4.1) \\
0.06 \\
(1.84) \\
0.06 \\
(1.59) \\
-0.047 \\
(-1.24) \\
-0.0456 \\
(-1.82) \\
-0.021 \\
(-1.8) \\
-0.0000 \\
(-1.48) \\
\\
\\
-0.021 \\
(-1.036) \\
\\
-0.0035 \\
(3.2) \\
-0.0052 \\
(-9.1) \\
-0.00426 \\
(-7.2) \\
0.096 \\
(0.47)\end{array}$ & $\begin{array}{c}0.41 \\
(2.5) \\
0.07 \\
(1.9) \\
0.07 \\
1.7) \\
-0.038 \\
(-0.9) \\
-0.030 \\
(-2.5) \\
-0.017 \\
(-2.8) \\
0.0000 \\
(1.5)\end{array}$ & $\begin{array}{c}0.32 \\
(3.3) \\
0.06 \\
(1.8) \\
0.06 \\
(1.6) \\
-0.028 \\
(-0.76) \\
-0.062 \\
(-2.4) \\
-0.027 \\
(-2.1) \\
-0.0002 \\
(-3.17) \\
\\
\\
0.014 \\
(0.67)\end{array}$ & $\begin{array}{c}0.30 \\
(3.1) \\
0.06 \\
(2.0) \\
0.06 \\
(1.8) \\
-0.020 \\
(-0.56) \\
-0.061 \\
(-2.6) \\
-0.026 \\
(-2.4) \\
-0.0002 \\
(-2.0)\end{array}$ \\
\hline \multicolumn{5}{|l|}{ Main statistics } \\
\hline $\begin{array}{c}\mathrm{R}^{2} \\
\text { Adjusted } \mathrm{R}^{2}\end{array}$ & $\begin{array}{l}0.652 \\
0.618\end{array}$ & $\begin{array}{l}0.656 \\
0.622\end{array}$ & $\begin{array}{l}0.681 \\
0.648\end{array}$ & $\begin{array}{l}0.687 \\
0.653\end{array}$ \\
\hline Durbin Watson & 2.05 & 2.03 & 2.0 & 1.99 \\
\hline
\end{tabular}

(1) As some heteroskedasticity has been detected., the t-statistics presented in this column are computed with the White heteroskedasticityconsistent standard errors.

(2) The working-age population is defined as those aged 15-64 (OECD usual definition).

(3) The relative size of youth/prime age population, defined as the size of population aged 15-24 over the population aged 25-54. 
Table 3

OLS Estimates of employment equations with and without break

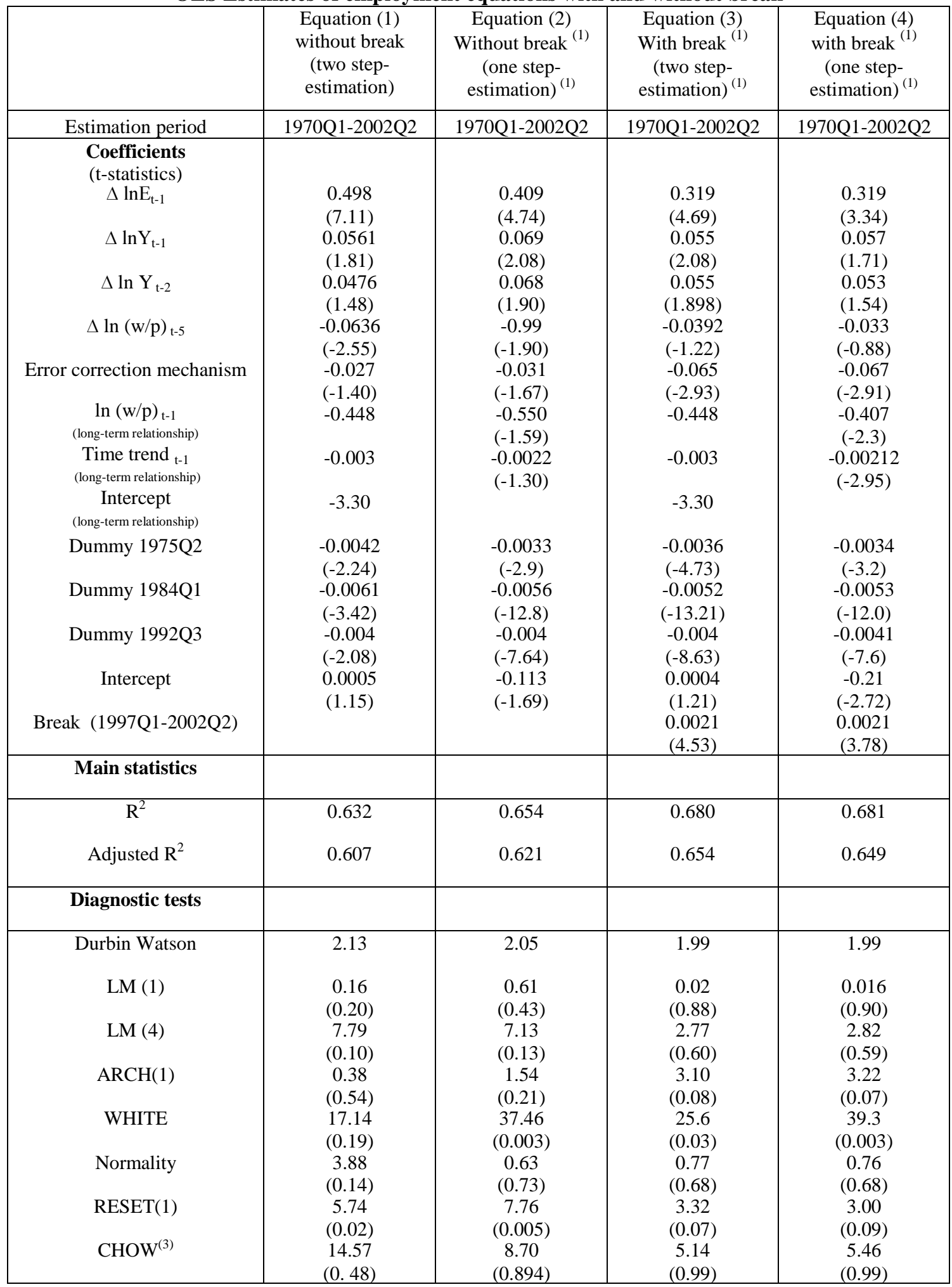

(1) As some heteroskedasticity has been detected., the t-statistics presented in this column are computed with the White heteroskedasticityconsistent standard errors.

${ }^{(2)}$ Asymptotic tests are presented.

${ }^{\text {(3) }}$ Predictive failure test over the period 1999Q1-2002Q2. 
Figure 1

Total employment: dynamic simulation without break

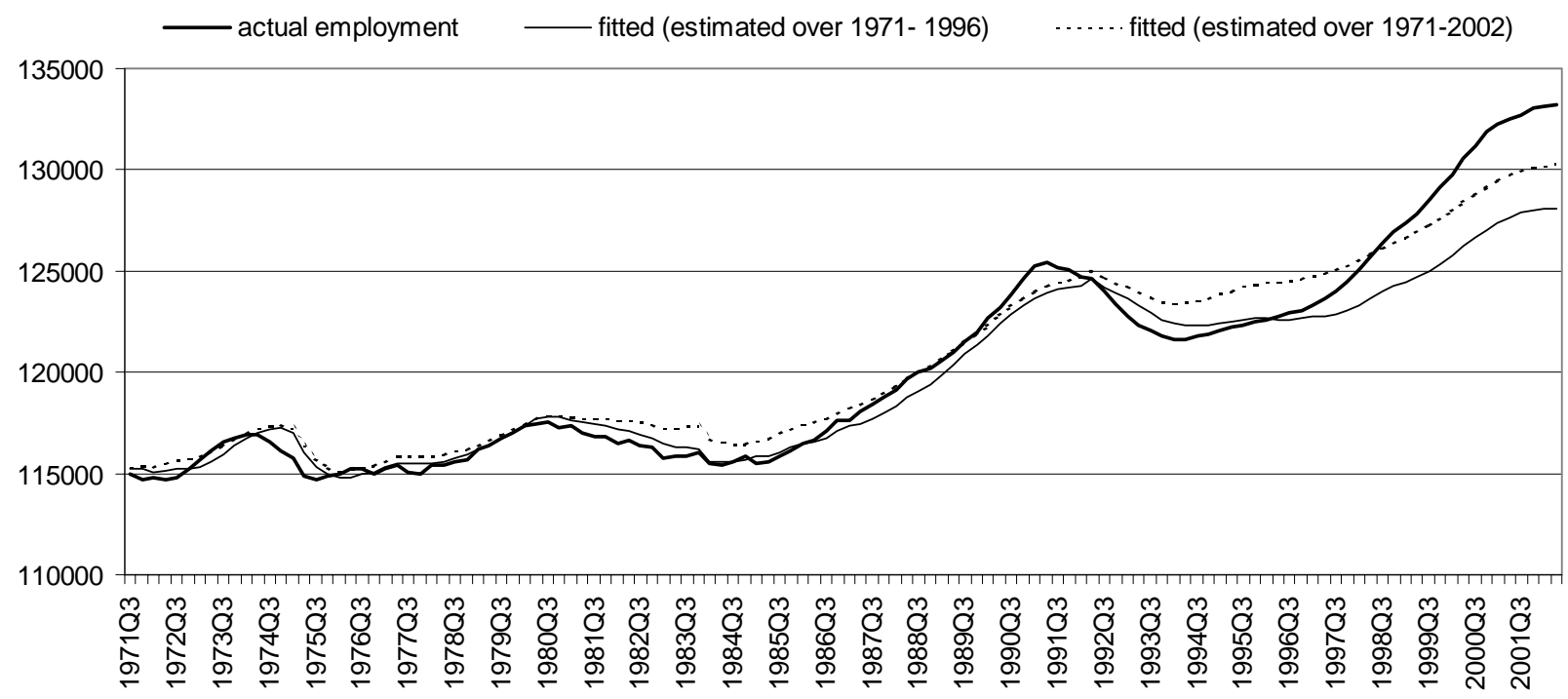

Figure 2

Dynamic contributions to the annual growth rate of total employment (from equation 1 in Table 3, without break)

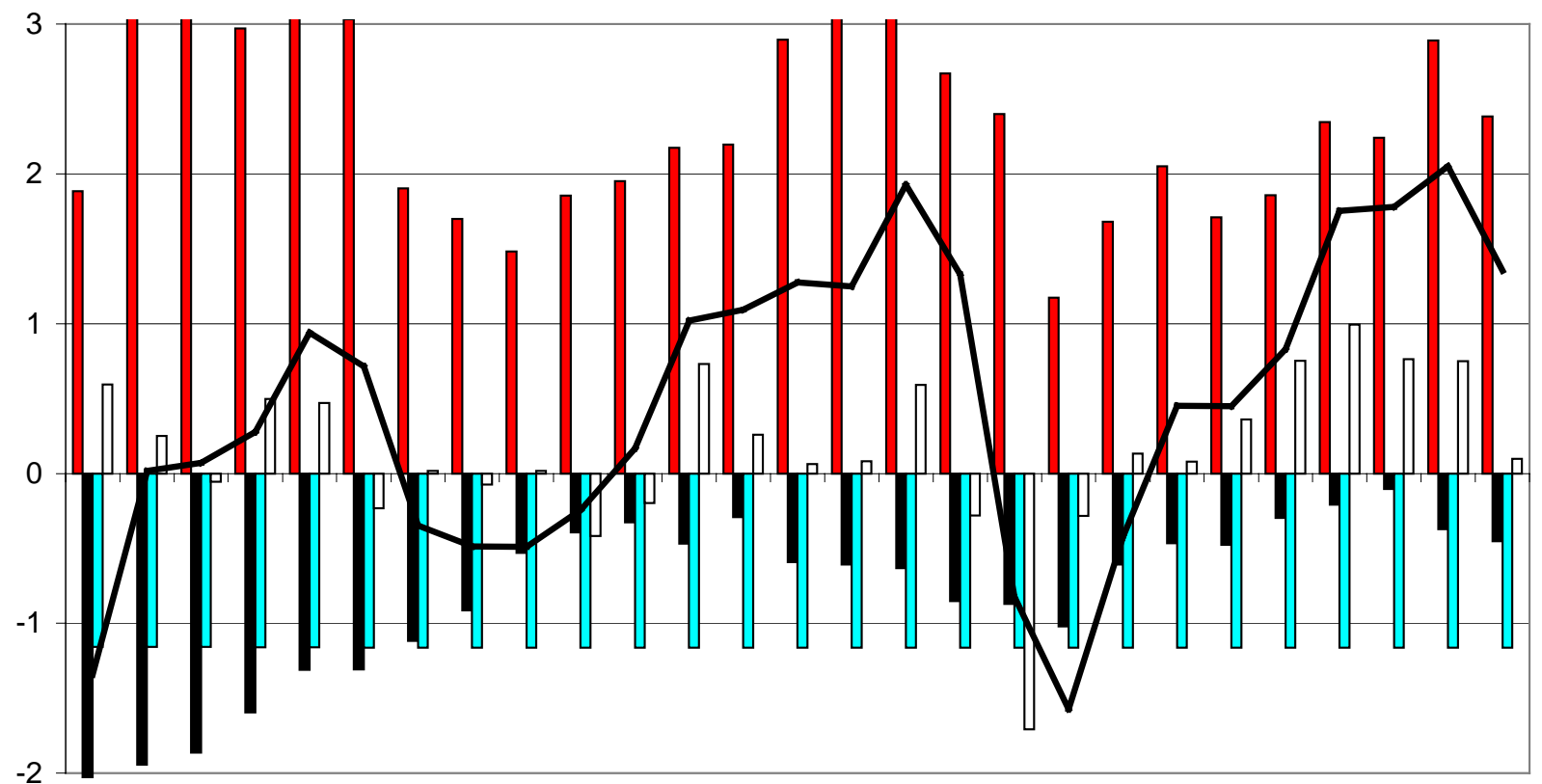

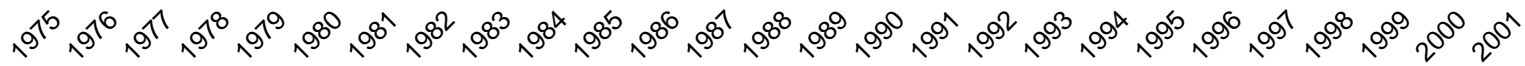
$\square$ GDP Real labour cost $\square$ Technology trend $\square$ Residuals $\quad$ Employment 
Table 4

Sequential selection of different possible breaks (from 1997 onwards) in the standard employment equation

\begin{tabular}{|c|c|c|c|c|}
\hline & Breaks in the equation & $\begin{array}{c}\text { The least significant break } \\
\text { (removed in the following steps) }\end{array}$ & $\begin{array}{l}\text { P-value of t- } \\
\text { statistics }\end{array}$ & $\begin{array}{l}\text { Adjusted R- } \\
\text { squared }\end{array}$ \\
\hline $\begin{array}{c}\text { Step 1 } \\
\text { (allowing for breaks } \\
\text { in all variables) }\end{array}$ & $\begin{array}{c}\Delta \ln \mathrm{E}_{\mathrm{t}-1} \Delta \ln \mathrm{Y}_{\mathrm{t}-1} \Delta \ln \mathrm{Y}_{\mathrm{t}-2} \Delta \ln (\mathrm{w} / \mathrm{p})_{\mathrm{t}-5} \\
\mathrm{ECM} \ln (\mathrm{w} / \mathrm{p})_{\mathrm{t}-1} \text { TIME-TREND } \\
\text { INTERCEPT }\end{array}$ & $\Delta \ln E_{t-1}$ & 0.76 & 0.636 \\
\hline Step 2 & $\begin{array}{c}\Delta \ln \mathrm{Y}_{\mathrm{t}-1} \Delta \ln \mathrm{Y}_{\mathrm{t}-2} \Delta \ln (\mathrm{w} / \mathrm{p})_{\mathrm{t}-5} \mathrm{ECM} \\
\ln \mathrm{w} / \mathrm{p}_{\mathrm{t}-5} \ln (\mathrm{w} / \mathrm{p})_{\mathrm{t}-1} \text { TIME-TREND } \\
\text { INTERCEPT }\end{array}$ & $\operatorname{Ln}(w / p)_{t-1}$ & 0.68 & 0.639 \\
\hline Step 3 & $\begin{array}{c}\Delta \ln \mathrm{Y}_{\mathrm{t}-1} \Delta \ln \mathrm{Y}_{\mathrm{t}-2} \Delta \ln (\mathrm{w} / \mathrm{p})_{\mathrm{t}-5} \mathrm{ECM} \\
\text { TIME-TREND INTERCEPT }\end{array}$ & $\begin{array}{c}\mathrm{ECM} \\
\left(\ln \mathrm{E}_{\mathrm{t}-1}-\ln \mathrm{Y}_{\mathrm{t}-1}\right)\end{array}$ & 0.76 & 0.636 \\
\hline Step 4 & $\begin{array}{c}\Delta \ln Y_{\mathrm{t}-1} \Delta \ln \mathrm{Y}_{\mathrm{t}-2} \Delta \ln (\mathrm{w} / \mathrm{p})_{\mathrm{t}-5} \\
\text { TIME-TREND INTERCEPT }\end{array}$ & TIME-TREND & 0.13 & 0.646 \\
\hline Step 5 & $\begin{array}{c}\Delta \ln Y_{\mathrm{t}-1} \\
\Delta \ln \mathrm{INTERCEPT}_{\mathrm{t}-2} \Delta \ln (\mathrm{w} / \mathrm{p})_{\mathrm{t}-5}\end{array}$ & $\Delta \ln (\mathrm{w} / \mathrm{p})_{\mathrm{t}-5}$ & 0.18 & 0.645 \\
\hline Step 6 & $\Delta \ln \mathrm{Y}_{\mathrm{t}-1} \Delta \ln \mathrm{Y}_{\mathrm{t}-2 \mathrm{INTERCEPT}}$ & $\Delta \ln Y_{t-2}$ & 0.07 & 0.647 \\
\hline Step 7 & $\Delta \ln Y_{\mathrm{t}-1}$ INTERCEPT & $\Delta \ln \mathrm{Y}_{\mathrm{t}-1}$ & 0.31 & 0.647 \\
\hline Final step & INTERCEPT & INTERCEPT & 0.002 & 0.649 \\
\hline
\end{tabular}

Note: This table is based on the re-estimation of equation 1 of Table 3, but using a one-step ECM estimation procedures and allowing for breaks in all variables (Step 1). The least significant break is removed sequentially in the following steps. The results are obtained with OLS regressions with standard errors corrected for possible heteroskedasticity and autocorrelation (Newey-West method).

Figure 3

Dynamic simulation with a break since 1997 observed versus fitted; level in thds

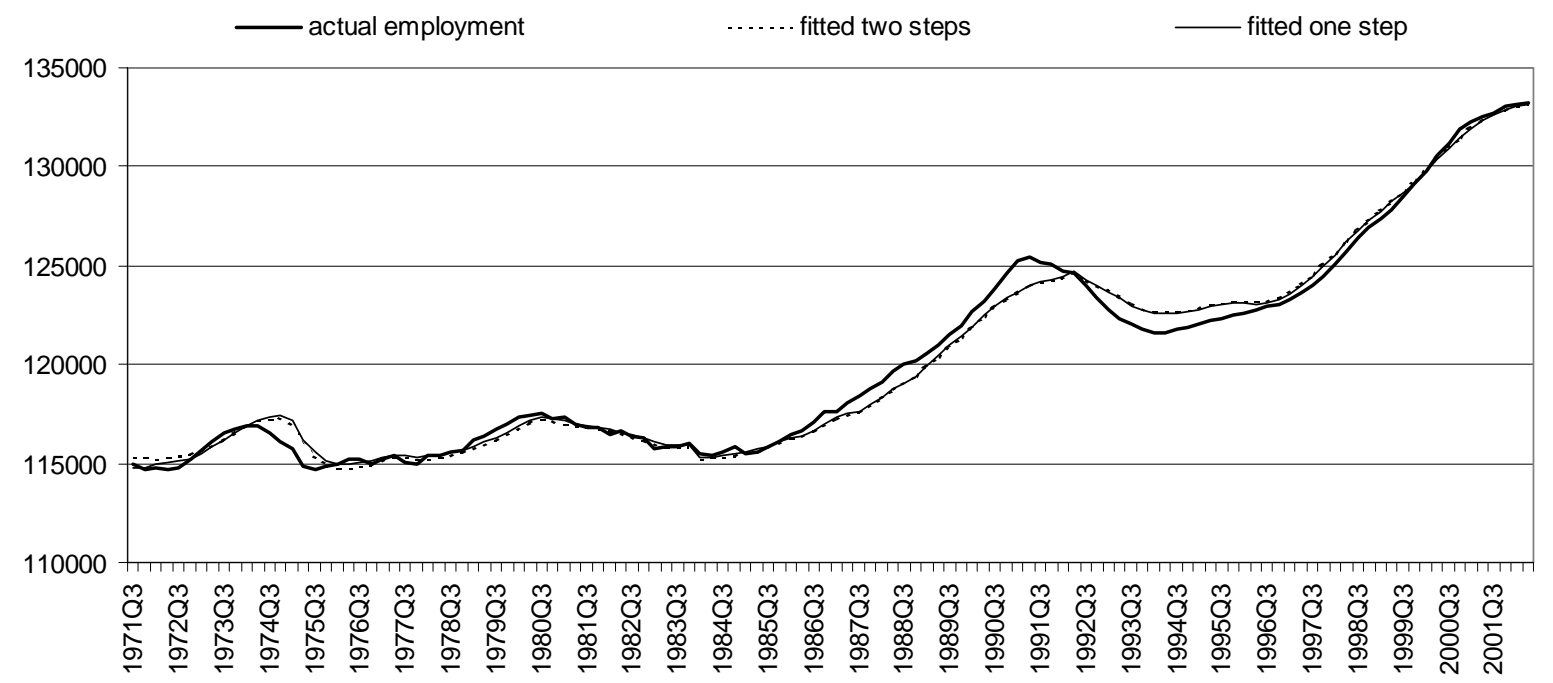


Figure 4

Forecasting performance between 1999Q2 and 2002Q2

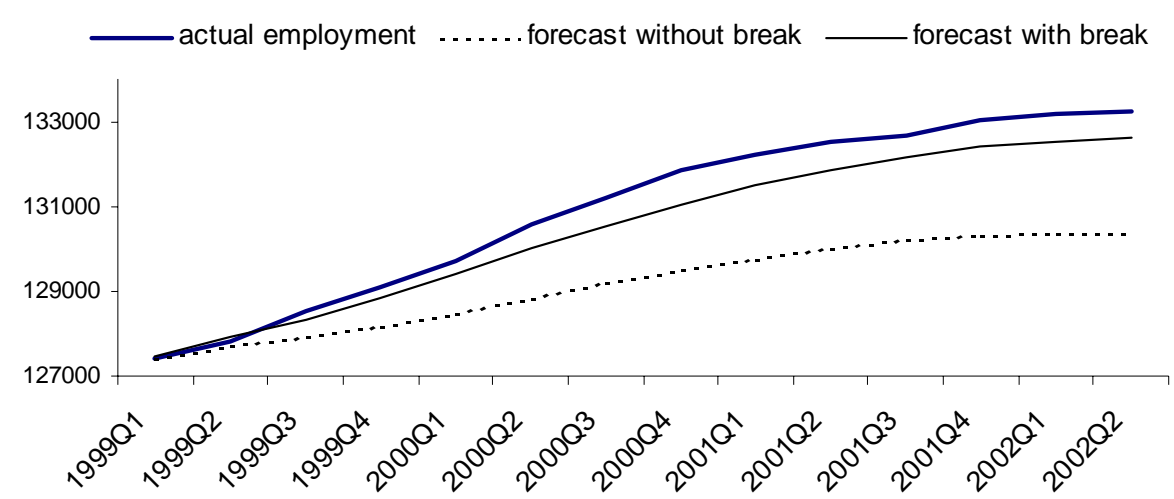

Table 5

Lagged reaction of employment to GDP growth (in quarters)

\begin{tabular}{|l|c|c|c|c|}
\hline period of estimation & 1970Q1 - 1996Q4 & 1970Q1 - 2002Q2 & 1985Q1 - 1996Q4 & 1985Q1 - 2002Q2 \\
\hline $50 \% *$ lag & $4.6(4.3)$ & $5.0(4.6)$ & $4.0(6.9)$ & $4.4(4.9)$ \\
\hline $80 \% *$ lag & $12.0(11.3)$ & $11.3(10.9)$ & $6.9(13.5)$ & $10.3(7.4)$ \\
\hline mean lag & $7.8(7.4)$ & $7.5(8.1)$ & $5.9(8.8)$ & $8.6(5.6)$ \\
\hline
\end{tabular}

Note: lagged reactions given by an equation including all lags of endogenous and exogenous variables up to 5 quarters, even those nonsignificant. Between brackets, lagged reactions given by an equation including the significant lags only (see equation 1 in Table 3).

* Number of quarters needed to reach $50 \%$ (80\%) of the long-term effect.

Table 6

Mean lag of employment to real labour costs (in quarters)

\begin{tabular}{|l|c|c|c|c|}
\hline period of estimation & 1970Q1 1996Q4 & 1970Q1 2002Q2 & 1985Q1 1996Q4 & 1985Q1 2002Q2 \\
\hline $50 \% *$ lag & $4.9(4.8)$ & $5.1(5.3)$ & $* *(* *)$ & $3.6(4.9)$ \\
\hline $80 \% *$ lag & $10.2(10.1)$ & $8.9(12.7)$ & $* *(* *)$ & $5.7(7.4)$ \\
\hline mean lag & $7.7(7.3)$ & $7.2(8.6)$ & $* *(* *)$ & $5.0(5.2)$ \\
\hline
\end{tabular}

Note: lagged reactions given by an equation including all lags of endogenous and exogenous variables up to 5 quarters, even those non-

significant. Between brackets, lagged reactions given by an equation including the significant lag only, see equation 1 in Table 3).

* Number of quarters needed to reach $50 \%$ (80\%) of the long-term effects.

** Non interpretable: long term elasticity has a positive sign, which is contrary to the theory.

Figure 5

Contribution of part-time jobs to total employment growth (p.p)

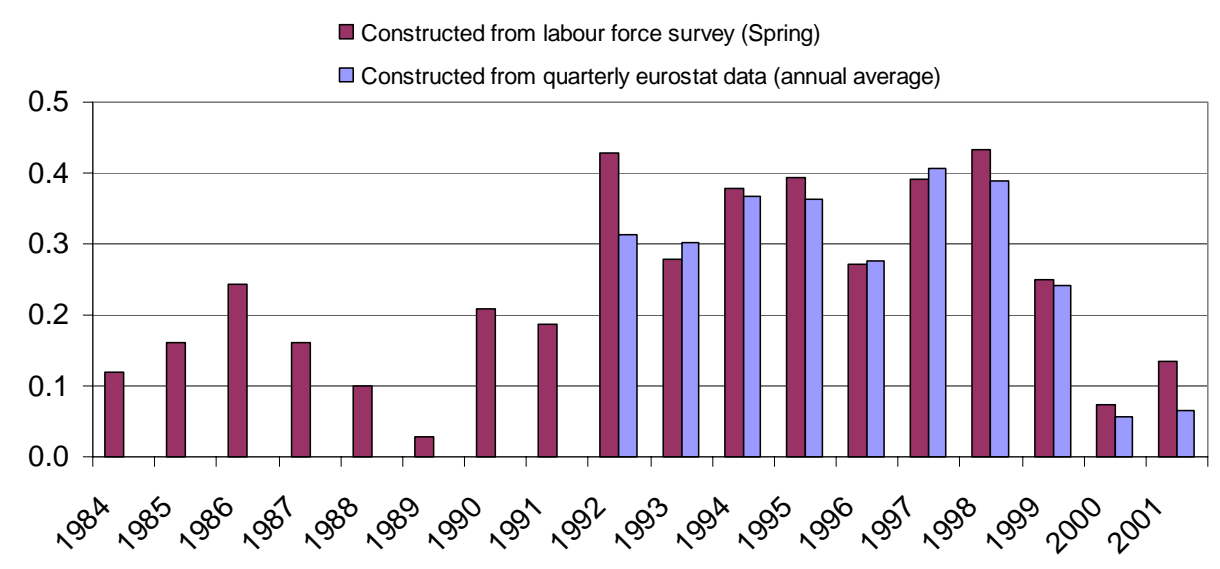


Table 7

Time series estimates with alternative measures of employment for euro area

\begin{tabular}{|c|c|c|}
\hline 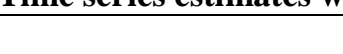 & Full-time equivalents & Hours worked $^{(1)}$ \\
\hline Estimation period & 1983Q4-2002Q1 & 1981Q3-2001Q4 \\
\hline \multicolumn{3}{|l|}{$\begin{array}{l}\text { Coefficients } \\
\text { (t-statistics) }\end{array}$} \\
\hline$\Delta \ln \mathrm{E}_{\mathrm{t}-1}$ & $\begin{array}{l}0.564 \\
(7.26)\end{array}$ & $\begin{array}{l}0.530 \\
(4.33)\end{array}$ \\
\hline$\Delta \ln \mathrm{Y}_{\mathrm{t}-2}$ & $\begin{array}{l}0.105 \\
(2.73)\end{array}$ & $\begin{array}{l}0.072 \\
(1.53)\end{array}$ \\
\hline$\Delta \ln \mathrm{Y}_{\mathrm{t}-3}$ & $\begin{array}{l}0.061 \\
(1.74)\end{array}$ & \\
\hline$\Delta \ln (\mathrm{w} / \mathrm{p})_{\mathrm{t}-2}$ & $\begin{array}{l}-0.067 \\
(-1.65)\end{array}$ & \\
\hline$\Delta \ln (\mathrm{w} / \mathrm{p})_{\mathrm{t}-5}$ & & $\begin{array}{l}-0.071 \\
(-2.01)\end{array}$ \\
\hline $\begin{array}{l}\text { Error correction } \\
\text { mechanisms }\end{array}$ & $\begin{array}{l}-0.033 \\
(-1.37)\end{array}$ & $\begin{array}{r}-0.0719 \\
(-277)\end{array}$ \\
\hline $\ln (\mathrm{w} / \mathrm{p})_{\mathrm{t}-1}$ & -0.320 & -0.148 \\
\hline $\begin{array}{l}\text { (long-term relationship) } \\
\text { Time trend }(-1)\end{array}$ & -0.0037 & -0.005 \\
\hline $\begin{array}{l}\text { (long-term relationship) } \\
\text { Intercept }\end{array}$ & -2.964 & 3.489 \\
\hline $\begin{array}{l}\text { (long-term relationship) } \\
\text { Dummy 1984Q1 }\end{array}$ & $\begin{array}{c}-0.0051 \\
(-3.51)\end{array}$ & $\begin{array}{c}-0.0035 \\
(-7.58)\end{array}$ \\
\hline Dummy 1992Q3 & $\begin{array}{c}-0.0049 \\
(-3.16)\end{array}$ & $\begin{array}{l}-0.005 \\
(-9.87)\end{array}$ \\
\hline Intercept & $\begin{array}{c}-0.00019 \\
(-0.52)\end{array}$ & $\begin{array}{l}0.516 \\
(2.76)\end{array}$ \\
\hline Break (1997Q1-2002Q2) & $\begin{array}{c}0.00083 \\
(2.01)\end{array}$ & $\begin{array}{c}0.00155 \\
(2.69)\end{array}$ \\
\hline \multicolumn{3}{|l|}{ Main statistics } \\
\hline $\mathrm{R}^{2}$ & 0.796 & 0.717 \\
\hline Adjusted $\mathrm{R}^{2}$ & 0.770 & 0.690 \\
\hline \multicolumn{3}{|l|}{ Diagnostic tests $^{(2)}$} \\
\hline Durbin Watson & 2.04 & 2.04 \\
\hline LM (1) & $\begin{array}{c}0.08 \\
(0.77)\end{array}$ & $\begin{array}{c}0.09 \\
(0.77)\end{array}$ \\
\hline LM (4) & $\begin{array}{l}7.73 \\
(0.10)\end{array}$ & $\begin{array}{l}3.46 \\
(0.48)\end{array}$ \\
\hline $\mathrm{ARCH}(1)$ & $\begin{array}{c}0.35 \\
(0.55)\end{array}$ & $\begin{array}{c}8.64 \\
(0.003)\end{array}$ \\
\hline WHITE & $\begin{array}{l}18.75 \\
(0.13)\end{array}$ & $\begin{array}{l}27.77 \\
(0.004)\end{array}$ \\
\hline Normality & $\begin{array}{l}2.32 \\
(0.31)\end{array}$ & $\begin{array}{l}20.03 \\
(0.0005)\end{array}$ \\
\hline $\operatorname{RESET}(1)$ & $\begin{array}{l}0.58 \\
(0.45)\end{array}$ & $\begin{array}{l}0.49 \\
(0.48)\end{array}$ \\
\hline $\mathrm{CHOW}^{(3)}$ & $\begin{array}{l}9.22 \\
(0.82)\end{array}$ & $\begin{array}{l}9.08 \\
(0.77)\end{array}$ \\
\hline
\end{tabular}

(1) As some heteroskedasticity has been detected., the t-statistics presented in this column are computed with the White heteroskedasticityconsistent standard errors. Euro area data on total hours worked are coming from Korteweg and Vijselaar (2002).

${ }^{(2)}$ Asymptotic tests are presented, as the hypothesis of normal residuals is not always fulfilled (e.g. equation in hours worked).

${ }^{(3)}$ Predictive failure test over the period 1999-2001 
Table 8

Testing a break in employment equation from 1997 with a panel of 21 OECD countries, 1977-2001

\begin{tabular}{|c|c|c|c|c|}
\hline Variables & (1) & (2) & (3) & (4) \\
\hline GDP growth & $\begin{array}{c}0.568 \\
(15.09)\end{array}$ & $\begin{array}{c}0.567 \\
(15.05)\end{array}$ & $\begin{array}{c}0.563 \\
(14.98)\end{array}$ & $\begin{array}{c}0.565 \\
(15.03)\end{array}$ \\
\hline GDP growth $(-1)$ & $\begin{array}{l}0.233 \\
(5.62)\end{array}$ & $\begin{array}{l}0.233 \\
(5.63)\end{array}$ & $\begin{array}{l}0.232 \\
(5.60)\end{array}$ & $\begin{array}{l}0.232 \\
(5.61)\end{array}$ \\
\hline GDP growth $(-2)$ & $\begin{array}{l}0.114 \\
(2.98)\end{array}$ & $\begin{array}{l}0.112 \\
(2.94)\end{array}$ & $\begin{array}{l}0.110 \\
(2.87)\end{array}$ & $\begin{array}{l}0.110 \\
(2.89)\end{array}$ \\
\hline Real labour cost & $\begin{array}{l}-0.252 \\
(-9.24)\end{array}$ & $\begin{array}{l}-0.252 \\
(-9.27)\end{array}$ & $\begin{array}{l}-0.249 \\
(-9.13)\end{array}$ & $\begin{array}{l}-0.249 \\
(-9.15)\end{array}$ \\
\hline Real labour cost $(-1)$ & $\begin{array}{l}-0.036 \\
(-1.32)\end{array}$ & $\begin{array}{l}-0.036 \\
(-1.33)\end{array}$ & $\begin{array}{l}-0.032 \\
(-1.17)\end{array}$ & $\begin{array}{l}-0.032 \\
(-1.17)\end{array}$ \\
\hline Break in euro area countries & $\begin{array}{l}0.304 \\
(1.24)\end{array}$ & & & \\
\hline Break in countries outside euro area & $\begin{array}{l}0.048 \\
(0.19)\end{array}$ & & & $\begin{array}{l}0.047 \\
(0.19)\end{array}$ \\
\hline Break in EU countries & & $\begin{array}{l}0.320 \\
(1.48)\end{array}$ & & \\
\hline Break in Non-EU & & $\begin{array}{l}-0.088 \\
(-0.30)\end{array}$ & $\begin{array}{l}-0.090 \\
(-0.30)\end{array}$ & \\
\hline Break in EU countries with faster employment growth from 1997 & & & $\begin{array}{l}0.745 \\
(2.25)\end{array}$ & \\
\hline Break in EU countries with unchanged employment growth from 1997 & & & $\begin{array}{l}0.018 \\
(0.06)\end{array}$ & \\
\hline Break in euro area countries with faster employment growth from 1997 & & & & $\begin{array}{l}0.741 \\
(2.24)\end{array}$ \\
\hline Break in euro area countries with unchanged employment growth from 1997 & & & & $\begin{array}{l}-0.194 \\
(-0.55)\end{array}$ \\
\hline Number of observations & 523 & 523 & 523 & 523 \\
\hline Number of countries & 21 & 21 & 21 & 21 \\
\hline R squared & 0.504 & 0.504 & 0.506 & 0.509 \\
\hline Poolability of euro area countries & $\begin{array}{c}X^{2}(5)=24.11 \\
(0.000)\end{array}$ & $\begin{array}{c}\chi^{2}(5)=24.29 \\
(0.000)\end{array}$ & $\begin{array}{c}\chi^{2}(5)=23.94 \\
(0.000)\end{array}$ & $\begin{array}{c}\chi^{2}(5)=25.00 \\
(0.000)\end{array}$ \\
\hline
\end{tabular}

Absolute value of t-statistics in parentheses

Data sources: OECD, economic outlook. Author's calculations.

Note: The equations are estimated by fixed-effects (within) regression. GDP and w/p have been instrumented in order to overcome endogeneity problems. The list of instruments is the contemporaneous export of goods and services and real labour costs lagged by two quarters. Euro area countries with faster employment growth from 1997 onwards are Belgium, France, Ireland, Italy, Spain and Netherlands. Euro area countries with unchanged employment growth from 1997 are Austria, Germany, Greece, Finland and Portugal. EU countries with faster employment growth from 1997 onwards are Belgium, France, Ireland, Italy, Spain and Netherlands. EU countries with unchanged employment growth from 1997 are Austria, Denmark, Germany, Greece, Finland, and Portugal, Sweden and the UK. These groups were constituted on the basis of the sign and significance of country break in preliminary regressions shown in Table 9. The poolability of restriction between the euro area countries and the other OECD countries is rejected by the Chow test on common slopes. This might generate a bias in parameter estimates, although the estimation may gain in efficiency when pooling. However, we keep pooling all OECD countries, as the purpose of the table is primarily to test the significance of the break with different groups of countries. 
Table 9

Testing a break in employment equation for each country from 1997 with a panel of 21 OECD countries, 1977-2001

\begin{tabular}{|c|c|c|c|}
\hline $\begin{array}{l}\text { Country } \\
\text { (euro area countries in italics) }\end{array}$ & (1) & (2) & (3) \\
\hline Austria & $\begin{array}{l}0.533 \\
(1.38)\end{array}$ & $\begin{array}{l}0.375 \\
(1.07)\end{array}$ & $\begin{array}{l}0.375 \\
(1.07)\end{array}$ \\
\hline Belgium & $\begin{array}{c}0.953 \\
(2.17)^{* *}\end{array}$ & $\begin{array}{c}0.753 \\
(1.82) *\end{array}$ & $\begin{array}{l}0.753 \\
(1.82)^{*}\end{array}$ \\
\hline Canada & $\begin{array}{l}0.676 \\
(0.68)\end{array}$ & $\begin{array}{l}0.320 \\
(0.39)\end{array}$ & $\begin{array}{l}0.320 \\
(0.39)\end{array}$ \\
\hline Switzerland & $\begin{array}{l}-0.236 \\
(-0.32)\end{array}$ & $\begin{array}{l}-0.269 \\
(-0.56)\end{array}$ & $\begin{array}{l}-0.269 \\
(-0.56)\end{array}$ \\
\hline Germany & $\begin{array}{l}-1.006 \\
(-0.21)\end{array}$ & $\begin{array}{l}-0.848 \\
(-0.22)\end{array}$ & $\begin{array}{l}-0.848 \\
(-0.22)\end{array}$ \\
\hline Denmark & $\begin{array}{l}0.219 \\
(0.28)\end{array}$ & $\begin{array}{l}-0.099 \\
(-0.17)\end{array}$ & $\begin{array}{l}-0.099 \\
(-0.17)\end{array}$ \\
\hline Spain & $\begin{array}{c}3.589 \\
(2.94) * * *\end{array}$ & $\begin{array}{c}3.264 \\
(3.46) * * *\end{array}$ & $\begin{array}{c}3.264 \\
(3.46) * * *\end{array}$ \\
\hline Finland & $\begin{array}{l}2.009 \\
(1.47)\end{array}$ & $\begin{array}{l}1.218 \\
(1.39)\end{array}$ & $\begin{array}{l}1.218 \\
(1.39)\end{array}$ \\
\hline France & $\begin{array}{c}1.240 \\
(2.99) * * *\end{array}$ & $\begin{array}{c}1.189 \\
(3.71)^{* * *}\end{array}$ & $\begin{array}{c}1.189 \\
(3.71)^{* * *}\end{array}$ \\
\hline United Kingdom & $\begin{array}{l}0.851 \\
(0.92)\end{array}$ & $\begin{array}{l}0.674 \\
(1.12)\end{array}$ & $\begin{array}{l}0.674 \\
(1.12)\end{array}$ \\
\hline Greece & $\begin{array}{l}-0.376 \\
(-0.33)\end{array}$ & $\begin{array}{l}-0.891 \\
(-0.97)\end{array}$ & $\begin{array}{l}-0.891 \\
(-0.97)\end{array}$ \\
\hline Ireland & $\begin{array}{c}2.987 \\
(2.19) * *\end{array}$ & $\begin{array}{l}1.554 \\
(1.48)\end{array}$ & $\begin{array}{l}1.554 \\
(1.48)\end{array}$ \\
\hline Italy & $\begin{array}{c}1.055 \\
(1.88)^{*}\end{array}$ & $\begin{array}{c}1.288 \\
(3.34) * * *\end{array}$ & $\begin{array}{c}1.288 \\
(3.34) * * *\end{array}$ \\
\hline Japan & $\begin{array}{c}-0.906 \\
(-2.47)^{* *}\end{array}$ & $\begin{array}{c}-0.469 \\
(-2.03)^{* *}\end{array}$ & $\begin{array}{c}-0.469 \\
(-2.03)^{* *}\end{array}$ \\
\hline Netherlands & $\begin{array}{c}1.460 \\
(2.21)^{* *}\end{array}$ & $\begin{array}{c}0.919 \\
(2.08) * *\end{array}$ & $\begin{array}{c}0.919 \\
(2.08) * *\end{array}$ \\
\hline Norway & $\begin{array}{l}0.376 \\
(0.50)\end{array}$ & $\begin{array}{l}0.219 \\
(0.43)\end{array}$ & $\begin{array}{l}0.219 \\
(0.43)\end{array}$ \\
\hline New Zealand & $\begin{array}{l}-0.401 \\
(-0.33)\end{array}$ & $\begin{array}{l}-0.319 \\
(-0.31)\end{array}$ & $\begin{array}{l}-0.319 \\
(-0.31)\end{array}$ \\
\hline Portugal & $\begin{array}{l}1.156 \\
(1.30)\end{array}$ & $\begin{array}{l}0.906 \\
(1.35)\end{array}$ & $\begin{array}{l}0.906 \\
(1.35)\end{array}$ \\
\hline Sweden & $\begin{array}{l}1.139 \\
(1.11)\end{array}$ & $\begin{array}{l}1.141 \\
(1.53)\end{array}$ & $\begin{array}{l}1.141 \\
(1.53)\end{array}$ \\
\hline United States & $\begin{array}{l}-0.495 \\
(-0.62) \\
\end{array}$ & $\begin{array}{l}-0.829 \\
(-1.25) \\
\end{array}$ & $\begin{array}{l}-0.829 \\
(-1.25) \\
\end{array}$ \\
\hline $\begin{array}{l}\text { Observations } \\
\text { Number of countries }\end{array}$ & $\begin{array}{c}523 \\
21\end{array}$ & $\begin{array}{c}523 \\
21\end{array}$ & $\begin{array}{c}523 \\
21\end{array}$ \\
\hline
\end{tabular}

Absolute value of $t$ statistics in parentheses.

* significant at 10\%,; **significant at 5\%; *** significant at $1 \%$.

Note: The break is modelled by a break in the intercept (additional growth). The dependent variable is annual employment growth, while the regressors are GDP growth and real compensation per employee. Various lag specifications have been used regressors lagged by 2 years (equation 1) so as to avoid endogeneity problems; contemporaneous regressors plus their lagged values by 1 and 2 years (equation 2) as lags of 3 years and more turn insignificant; lagged regressors by 1 and 2 years (equation 3). The three equations are estimated by generalised least squares with country fixed effects, allowing for heteroskedastic errors and common-across-group first order serial correlation. 
Table 10

Impact of sectoral composition on total employment growth

\begin{tabular}{|c|c|c|c|c|c|c|}
\hline \multirow[t]{2}{*}{ Industrial sectors } & \multicolumn{2}{|c|}{$\begin{array}{l}\text { Average annual growth rate } \\
\text { of employment }\end{array}$} & \multicolumn{2}{|c|}{ Share in total employment } & \multicolumn{2}{|c|}{$\begin{array}{l}\text { Decomposition of employment growth } \\
\text { 1997-2001 }\end{array}$} \\
\hline & 1986-1991 & $1997-2001$ & 1986-1991 & $1997-2001$ & $\begin{array}{l}\text { Value-added } \\
\text { growth }\end{array}$ & $\begin{array}{l}\text { Employment } \\
\text { intensity }\end{array}$ \\
\hline Agriculture & -3.7 & -1.5 & 7.1 & 4.5 & 0.8 & -1.8 \\
\hline Industry excluding construction & 0.5 & 0.2 & 24.8 & 20.2 & 2.3 & 0.1 \\
\hline Construction & 1.7 & 0.6 & 7.3 & 7.1 & 0.2 & 2.6 \\
\hline $\begin{array}{l}\text { Trade, repairs, hotels and restaurant, transport } \\
\text { and communication }\end{array}$ & 2.0 & 1.9 & 24.0 & 25.1 & 3.7 & 0.5 \\
\hline $\begin{array}{l}\text { Financial, real estate renting and business } \\
\text { services }\end{array}$ & 4.9 & 4.8 & 9.8 & 13.6 & 3.5 & 1.4 \\
\hline $\begin{array}{l}\text { Public administration, education, health and } \\
\text { other services }\end{array}$ & 2.4 & 1.4 & 27.0 & 29.5 & 1.3 & 1.0 \\
\hline Total & 1.6 & 1.5 & 100 & 100 & 2.6 & 0.6 \\
\hline $\begin{array}{l}\text { Total with the sectoral structure of } 1986- \\
1990 .\end{array}$ & 1.6 & 1.3 & & & & \\
\hline
\end{tabular}

Data sources: ESA95 national account, Eurostat. OECD, STAN databases. Author's calculations.

${ }^{1}$ Ratio employment growth / value-added growth. In other words, this is the empirical elasticity of employment to value added. 
Table 11

Panel data models of employment including labour market institutions

Dependent variable: total employment (level in logarithm/employment rate)

(Euro area countries ${ }^{(1)}$. 1960-1997)

\begin{tabular}{|c|c|c|c|c|c|c|}
\hline Dependent variables & \begin{tabular}{|c|}
$(1)$ \\
Employment \\
(in log)
\end{tabular} & \begin{tabular}{|c|}
$(2)$ \\
employment \\
(in log)
\end{tabular} & $\begin{array}{c}\text { (3) } \\
\text { employment } \\
\text { (in log) }\end{array}$ & \begin{tabular}{|c|}
$(4)$ \\
employment \\
(in log)
\end{tabular} & \begin{tabular}{|c|}
$(5)$ \\
employment \\
rate $(\%)$
\end{tabular} & $\begin{array}{c}(6) \\
\text { employment } \\
\text { rate }(\%)\end{array}$ \\
\hline \multicolumn{7}{|l|}{ Macroeconomic variables } \\
\hline Ln (Employment) (-1) & $\begin{array}{c}0.862 \\
(19.55)\end{array}$ & $\begin{array}{c}0.856 \\
(18.68)\end{array}$ & $\begin{array}{c}0.857 \\
(18.71)\end{array}$ & $\begin{array}{c}0.788 \\
(17.52)\end{array}$ & & \\
\hline Employment rate $(-1)$ & & & & & $\begin{array}{c}0.854 \\
(31.17)\end{array}$ & $\begin{array}{c}0.771 \\
(23.71)\end{array}$ \\
\hline $\operatorname{Ln}(\mathrm{GDP})$ & $\begin{array}{l}-0.003 \\
(-0.77)\end{array}$ & $\begin{array}{l}0.008 \\
(0.21)\end{array}$ & $\begin{array}{l}0.009 \\
(0.23)\end{array}$ & $\begin{array}{l}0.003 \\
(0.08)\end{array}$ & & \\
\hline Ln (Real compensation per employee) & $\begin{array}{l}-0.05 \\
(-1.80)\end{array}$ & $\begin{array}{l}-0.045 \\
(-1.49)\end{array}$ & $\begin{array}{l}-0.041 \\
(-1.33)\end{array}$ & $\begin{array}{l}-0.083 \\
(-2.65)\end{array}$ & & \\
\hline \multicolumn{7}{|l|}{ Institutions } \\
\hline Employment protection & $\begin{array}{l}-0.014 \\
(-2.16)\end{array}$ & $\begin{array}{l}-0.013 \\
(-1.93)\end{array}$ & $\begin{array}{l}-0.014 \\
(-2.06)\end{array}$ & $\begin{array}{l}0.113 \\
(3.71)\end{array}$ & $\begin{array}{l}-0.003 \\
(-0.81)\end{array}$ & $\begin{array}{l}0.010 \\
(0.92)\end{array}$ \\
\hline Total taxes on labour & $\begin{array}{l}-0.137 \\
(-3.09)\end{array}$ & $\begin{array}{l}-0.147 \\
(-2.92)\end{array}$ & $\begin{array}{l}-0.147 \\
(-2.91)\end{array}$ & $\begin{array}{l}-0.257 \\
(-1.87)\end{array}$ & $\begin{array}{l}-0.101 \\
(-4.34)\end{array}$ & $\begin{array}{l}-0.161 \\
(-2.79)\end{array}$ \\
\hline Unionisation & $\begin{array}{l}-0.036 \\
(-1.52)\end{array}$ & $\begin{array}{l}-0.040 \\
(1.58)\end{array}$ & $\begin{array}{l}-0.035 \\
(-1.34)\end{array}$ & $\begin{array}{l}0.101 \\
(0.91)\end{array}$ & $\begin{array}{r}-0.005 \\
(0.42)\end{array}$ & $\begin{array}{l}0.128 \\
(2.92)\end{array}$ \\
\hline Bargaining coordination & & $\begin{array}{l}0.007 \\
(1.85)\end{array}$ & $\begin{array}{l}-0.024 \\
(-0.60)\end{array}$ & $\begin{array}{l}0.079 \\
(3.28)\end{array}$ & $\begin{array}{l}0.003 \\
(1.61)\end{array}$ & $\begin{array}{l}0.027 \\
(2.85)\end{array}$ \\
\hline $\begin{array}{l}\text { Bargaining coordination squared } \\
\text { (U-shape curve hypothesis) }\end{array}$ & & & $\begin{array}{l}0.007 \\
(0.78)\end{array}$ & & & \\
\hline Unemployment benefits replacement ratio & & $\begin{array}{l}0.005 \\
(0.19)\end{array}$ & $\begin{array}{l}0.008 \\
(0.28)\end{array}$ & $\begin{array}{l}0.112 \\
(1.32)\end{array}$ & $\begin{array}{l}-0.024 \\
(-2.06)\end{array}$ & $\begin{array}{l}0.014 \\
(0.37)\end{array}$ \\
\hline Unemployment benefits duration & & $\begin{array}{l}0.003 \\
(0.35)\end{array}$ & $\begin{array}{l}0.003 \\
(0.48)\end{array}$ & $\begin{array}{l}0.006 \\
(0.25)\end{array}$ & $\begin{array}{l}0.001 \\
(0.33)\end{array}$ & $\begin{array}{l}0.023 \\
(2.38)\end{array}$ \\
\hline Interactions between institutions & & & & & & \\
\hline Employment protection* Total taxes on labour & & & & $\begin{array}{l}-0.034 \\
(-0.47)\end{array}$ & & $\begin{array}{l}0.051 \\
(1.96)\end{array}$ \\
\hline Employment protection* Bargaining coordination & & & & $\begin{array}{l}-0.050 \\
(-4.72)\end{array}$ & & $\begin{array}{l}-0.003 \\
(-0.82)\end{array}$ \\
\hline Employment protection* Unionisation & & & & $\begin{array}{l}0.063 \\
(1.85)\end{array}$ & & $\begin{array}{l}-0.025 \\
(-1.68)\end{array}$ \\
\hline Employment protection* Unemployment benefits duration & & & & $\begin{array}{l}-0.001 \\
(-0.05)\end{array}$ & & $\begin{array}{l}-0.021 \\
(-2.40)\end{array}$ \\
\hline Employment protection* Unemployment benefits replacement ratio & & & & $\begin{array}{l}-0.053 \\
(-0.96)\end{array}$ & & $\begin{array}{l}-0.005 \\
(-0.24)\end{array}$ \\
\hline Total taxes on labour* Unionisation & & & & $\begin{array}{l}-0.087 \\
(-2.66)\end{array}$ & & $\begin{array}{l}-0.044 \\
(-3.43)\end{array}$ \\
\hline Total taxes on labour* Bargaining coordination & & & & $\begin{array}{l}0.074 \\
(2.20)\end{array}$ & & $\begin{array}{l}-0.009 \\
(-0.56)\end{array}$ \\
\hline Unemployment benefits replacement ratio* Unemployment benefits duration & & & & $\begin{array}{l}-0.026 \\
(-0.50)\end{array}$ & & $\begin{array}{l}-0.014 \\
(-0.54)\end{array}$ \\
\hline Intercept & $\begin{array}{l}2.379 \\
(3.70)\end{array}$ & $\begin{array}{l}2.268 \\
(3.41)\end{array}$ & $\begin{array}{l}2.242 \\
(3.38)\end{array}$ & $\begin{array}{l}3.393 \\
(5.18)\end{array}$ & $\begin{array}{l}0.149 \\
(5.30)\end{array}$ & $\begin{array}{l}0.153 \\
(4.90)\end{array}$ \\
\hline Country specific trends & No & No & No & No & Yes & Yes \\
\hline Number of observations & 289 & 289 & 289 & 289 & 330 & 330 \\
\hline Number of countries & 9 & 9 & 9 & 9 & 10 & 10 \\
\hline Cointegration (Stationarity of residuals - Maddala-Wu test) & $\begin{array}{c}\chi^{2}(18)=68.82 \\
(0.000)\end{array}$ & $\begin{array}{c}\chi^{2}(18)=68.43 \\
(0.000)\end{array}$ & $\begin{array}{c}\chi^{2}(18)=73.54 \\
(0.000)\end{array}$ & $\begin{array}{c}\chi^{2}(18)=73.53 \\
(0.000)\end{array}$ & $\mid \begin{array}{c}\chi^{2}(20)=59.5 \\
(0.000)\end{array}$ & $\begin{array}{c}\chi^{2}(20)=60.8 \\
(0.000)\end{array}$ \\
\hline Poolability of euro area countries ${ }^{(2)}$ & $\begin{array}{c}\mathrm{X}^{2}(6)=112.9 \\
(0.000)\end{array}$ & $\begin{array}{c}\chi^{2}(9)=114.8 \\
(0.000)\end{array}$ & $\begin{array}{c}\chi^{2}(10)=110.81 \\
(0.000)\end{array}$ & $\begin{array}{c}\chi^{2}(17)=99.5 \\
(0.000)\end{array}$ & $\begin{array}{c}\chi^{2}(7)=159.8 \\
(0.000)\end{array}$ & $\begin{array}{c}\chi^{2}(15)=116.3 \\
(0.000)\end{array}$ \\
\hline
\end{tabular}

Sources: OECD economic outlook, Nickell and Nunziata (2001). Author's calculations.

${ }^{(1)}$ Countries included: Austria, Belgium, Finland, France, Germany, Ireland, Italy, Netherlands and Spain. Portugal is included in equation (5) and (6),

${ }^{(2)}$ Chow test on common slopes between the euro area and other OECD countries (Australia, Canada, Japan, Norway, Sweden, Switzerland, UK, US, Denmark and New Zealand).

Note: The equations are estimated by generalised least squares allowing for heteroskedastic errors and common-across-group first order serial correlation. Each equation contains country dummies and time dummies (fixed effects). Nickell (1981) shows that the bias of dynamic (with lagged dependent variable among the regressors) fixed effects models with first order serial correlation is o(1/T) and therefore becomes less important as T grows. Moreover, Judson and Owen (1999) showed that the fixed effect estimator performs as well as many alternatives when $T=30$ (see Nunziata, 2001). Employment, GDP and real labour cost are included with a lag of two years to tackle endogeneity problems (reverse causality). The panel is unbalanced as some data are missing for the 1960s and 1970s. 
Table 12

Panel data models of employment including active labour market policies

Dependent variable: total employment (level in logarithm/employment rate)

(Unbalanced euro country panel $\left.{ }^{(1)}, 1988-2001\right)$

\begin{tabular}{|c|c|c|c|c|}
\hline Variables & $\begin{array}{c}\text { (1) } \\
\text { Employment (in } \\
\log )\end{array}$ & \begin{tabular}{|c|}
$(2)$ \\
employment (in \\
$\log )$
\end{tabular} & \begin{tabular}{|c|}
$(3)$ \\
employment (in \\
$\log )$
\end{tabular} & \begin{tabular}{|c|}
$(4)$ \\
employment rate \\
$(\%)$
\end{tabular} \\
\hline Ln (Employment) (-1) & & & & $\begin{array}{c}0.904 \\
(17.19)\end{array}$ \\
\hline Employment rate (-1) & $\begin{array}{c}0.873 \\
(12.84)\end{array}$ & $\begin{array}{c}0.865 \\
(11.58)\end{array}$ & $\begin{array}{c}0.877 \\
(11.35)\end{array}$ & \\
\hline $\operatorname{Ln}(\mathrm{GDP})(-2)$ & $\begin{array}{l}0.068 \\
(0.82)\end{array}$ & $\begin{array}{l}0.090 \\
(0.97)\end{array}$ & $\begin{array}{l}0.073 \\
(0.70)\end{array}$ & \\
\hline Ln (Real compensation per employee) $(-2)$ & $\begin{array}{l}-0.050 \\
(-0.83)\end{array}$ & $\begin{array}{l}-0.038 \\
(-0.48)\end{array}$ & $\begin{array}{l}-0.011 \\
(-0.13)\end{array}$ & \\
\hline Public employment services (-2) & $\begin{array}{l}-0.022 \\
(-0.37)\end{array}$ & $\begin{array}{l}-0.059 \\
(-0.84)\end{array}$ & $\begin{array}{l}-0.058 \\
(-0.76)\end{array}$ & $\begin{array}{l}0.009 \\
(0.29)\end{array}$ \\
\hline Labour market training $(-2)^{(2)}$ & $\begin{array}{l}-0.049 \\
(-1.77)\end{array}$ & $\begin{array}{l}-0.055 \\
(-1.83)\end{array}$ & $\begin{array}{l}-0.053 \\
(-1.56)\end{array}$ & $\begin{array}{l}-0.021 \\
(-1.91)\end{array}$ \\
\hline Tobal subsidised employment $(-2)(a+b)$ & $\begin{array}{l}0.010 \\
(0.78)\end{array}$ & & & \\
\hline Subsidies to regular employment in the private sector $(-2)(a)$ & & $\begin{array}{l}0.031 \\
(1.10)\end{array}$ & $\begin{array}{l}0.026 \\
(0.69)\end{array}$ & $\begin{array}{l}0.020 \\
(1.76)\end{array}$ \\
\hline Direct job creation (public or non-profit) $(-2)(b)$ & & $\begin{array}{l}0.009 \\
(0.50)\end{array}$ & $\begin{array}{l}0.010 \\
(0.44)\end{array}$ & $\begin{array}{l}0.000 \\
(0.01)\end{array}$ \\
\hline Youth measures $(-2)^{(3)}$ & & & $\begin{array}{l}-0.026 \\
(-0.47)\end{array}$ & \\
\hline Constant & $\begin{array}{l}0.779 \\
(0.73)\end{array}$ & $\begin{array}{l}0.381 \\
(0.31)\end{array}$ & $\begin{array}{l}0.402 \\
(0.27)\end{array}$ & $\begin{array}{l}0.067 \\
(1.63)\end{array}$ \\
\hline Country specific trends & No & No & No & Yes \\
\hline Number of observations & 138 & 125 & 117 & 134 \\
\hline Number of countries & 10 & 10 & 10 & 10 \\
\hline Cointegration (Stationarity of residuals - Maddala-Wu test) & $\begin{array}{c}\chi^{2}(18)=33.9 \\
(0.012)\end{array}$ & $\begin{array}{c}\chi^{2}(18)=48.14 \\
(0.000)\end{array}$ & $\begin{array}{c}\chi^{2}(18)=51.8 \\
(0.000)\end{array}$ & $\begin{array}{c}\chi^{2}(20)=23.6 \\
(0.259)\end{array}$ \\
\hline Poolability of euro area countries ${ }^{(4)}$ & $\begin{array}{c}\chi^{2}(6)=5.33 \\
(0.502)\end{array}$ & $\begin{array}{c}\chi^{2}(7)=5.48 \\
(0.602)\end{array}$ & $\begin{array}{c}\chi^{2}(8)=13.14 \\
(0.107)\end{array}$ & $\begin{array}{c}\chi^{2}(7)=68.2 \\
(0.000)\end{array}$ \\
\hline
\end{tabular}

Data sources: OECD economic outlook. Active labour market policies (ALMP) data stems from the OECD database on labour market programmes. Author's calculations.

${ }^{(1)}$ Countries included: Austria, Belgium, Finland, France, Germany, Ireland, Italy, Netherlands, Spain and Portugal.

(2) Training for employed and unemployed adults and those at risk

${ }^{(3)}$ Measures for unemployed and disadvantaged youth and support of apprenticeship and related forms of general youth training

(4) Chow test on common slopes between the euro area countries and other OECD countries (Australia, Canada, Japan, Norway, Sweden, Switzerland, UK, US, Denmark and New Zealand).

Note: The equations are estimated by generalised least squares allowing for heteroskedastic errors and common-across-group first order serial correlation. Each equation contains country dummies and time dummies (fixed effects). Nickell (1981) shows that the bias of dynamic (with lagged dependent variable among the regressors) fixed effects models with first order serial correlation is o(1/T) and therefore becomes less important as T grows. Moreover, Judson and Owen (1999) showed that the fixed effect estimator performs as well as many alternatives when $T=30$ (see Nunziata, 2001). Employment, GDP and real labour cost are included with a lag of two years to tackle endogeneity problems (reverse causality). In order to take into account that active labour market measures are likely to impact employment gradually and to correct for possible endogeneity, ALMP (expressed as the share of ALMP expenditures in GDP) are estimated with a two year lag. The panel is unbalanced as some data are missing for the 19960 s and 1970 s. 
Figure 6a

Relation between break in employment pattern and changes in employment structure

Data sources: New Cronos, Eurostat. The break in employment growth since 1997 corresponds to the panel estimation (model 1) reported in Table 9. Non significant breaks are set at zero.

Figure $6 b$

Relation between break in employment pattern and changes in institutions

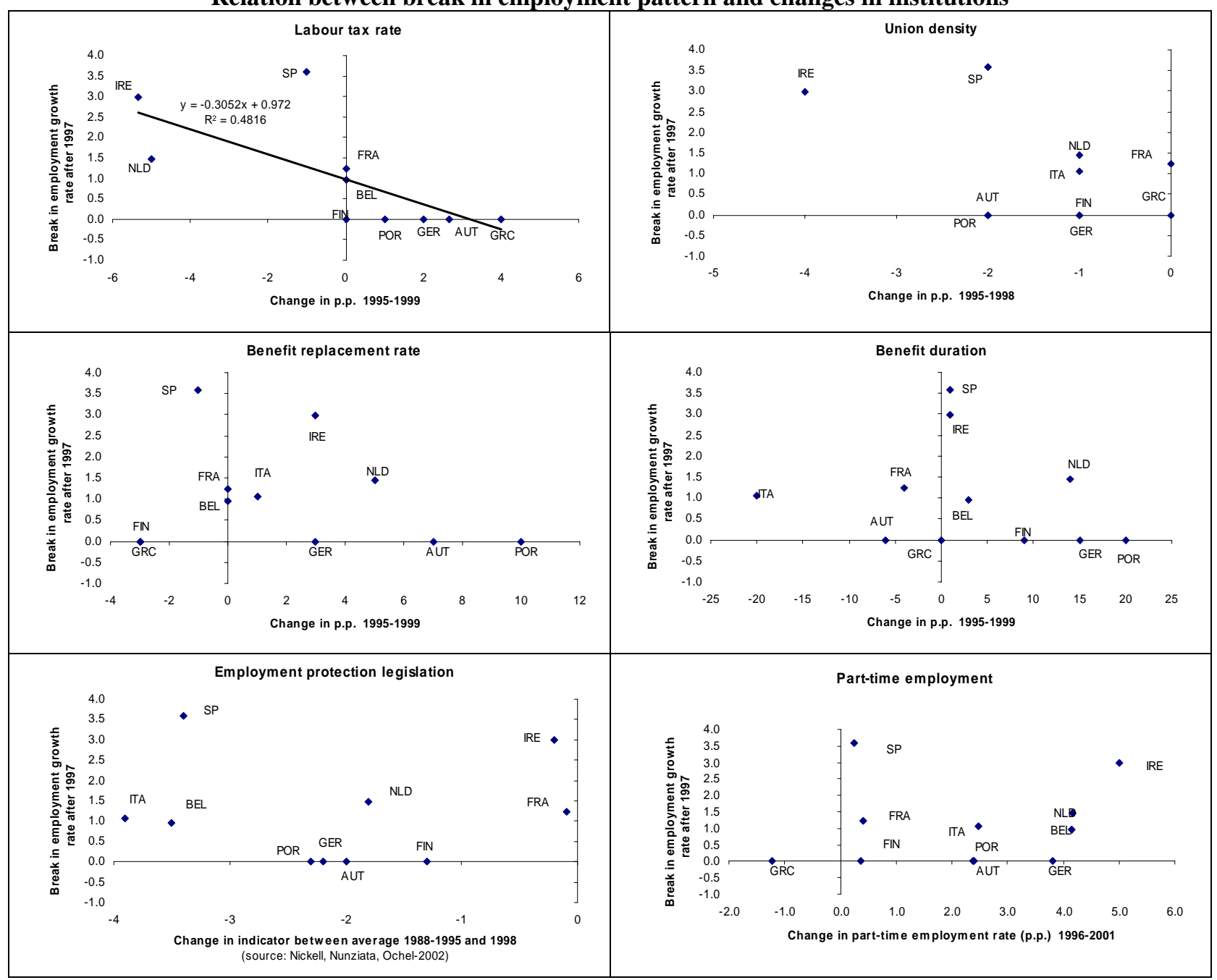


Figure 6 b (continued)

Relation between break in employment pattern and changes in institutions

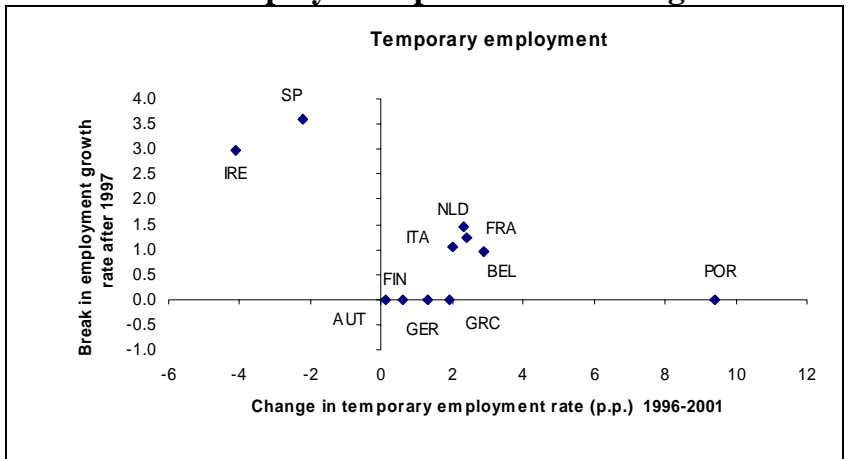

Data sources: OECD. Nickell and Nunziata (2001), Nickell, Nunziata and Ochel (2002). Labour Force Surveys (Eurostat). The break in employment growth since 1997 corresponds to the panel estimation (model 1) reported in Table 9. The results for bargaining co-ordinations are not displayed given the absence of any significant changes in most countries in the late 1990s.

Figure 6c

Relation between break in employment pattern and changes in active labour market policies

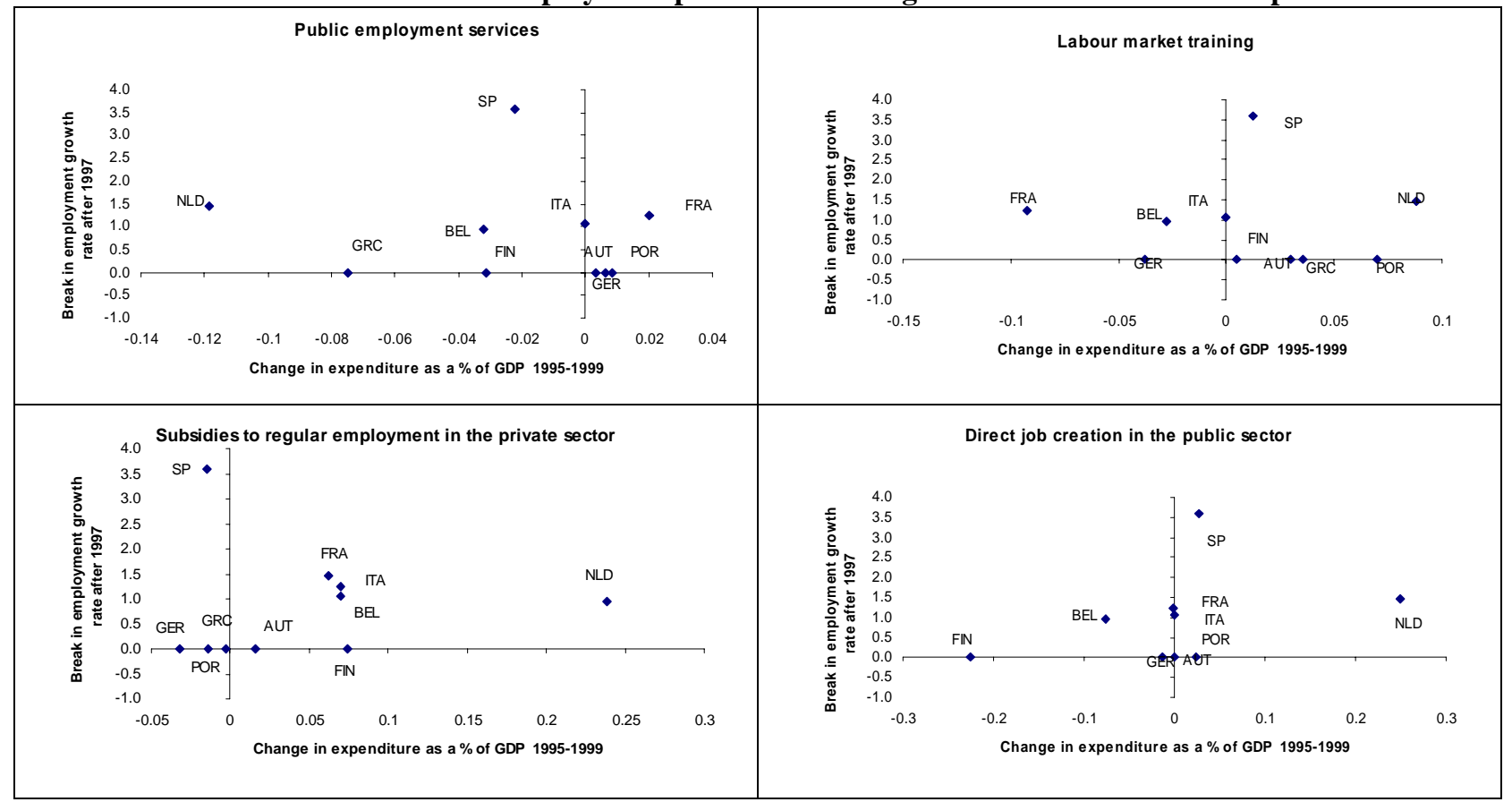

Data sources: OECD. The break in employment growth since 1997 corresponds to the panel estimation (model 1) reported in Table 9. 


\section{ANNEX \\ Detailed results of the estimation of a standard employment equation for the euro area. (Addendum to section 2.3)}

The two-step estimation without break, called equation 1 in the rest of the text and reported in column 1 of Table 3, yields similar results to the one-step estimation (column 2 of Table 3). The residuals are normal and there is no serial correlation. The null hypothesis of no serial correlation is not rejected by Ljung-Box Q test. This is confirmed by the Breusch-Godfrey Lagrange multiplier test (with one and four lags) at $5 \%$. Heteroskedasticity is rejected with the White test $\chi^{2}(13)$ at $1 \%$. The equation estimation results from a "general-to-specific" approach. The chosen length of the lag distribution, i.e. 5, is that associated with the lowest value of both the Akaike Information Criterion and the Schwarz Criterion. The existence of the cointegration relation, captured by the ECM term, is established according to two methods. First, we check that the residual of the long-run relationship is stationary with both Augmented Dickey-Fuller and Phillips-Perron Tests. We use the asymptotic critical values tabulated by Phillips and Ouliaris, which should be applied to residuals from spurious cointegrating regressions (Hamilton, 1994). Second, we use the Johansen Test based on the estimation of a VECM. Both trace statistic and maximum eigen value statistics confirm the existence of a cointegration relationship between GDP, real labour cost and employment.

The equation contains time dummies, encompassing specific time effects. Even though the choice of dummies and that of the specific quarters are somewhat arbitrary, their inclusion increases substantially the fit of the equation, while having an economic meaning. The first dummy (1975Q2) may partly capture adverse effects of the first oil shock in the mid-1970s, such as the deterioration in employers' confidence and the rise in economic uncertainty. The second dummy (1984Q1) might refer to the negative impact on employers' expectation of the tightening fiscal and monetary policy in France, implemented after the short-lived and unsuccessful expansionary macroeconomic policy conducted in 1981-1982. The third (1992Q3) is related to the strong and temporary increase in value added in the German building sector, caused by public subsidies in the context of German Reunification. Those few quarterly dummies only capture part of those effects, but correct for the strongest outliers. Conversely, dummies capturing asymmetry of labour demand across the economic cycle (e.g. negative dummy when the level of GDP is decreasing over four quarters) turn out not to be significant.

Equation 1 allows us to determine the impact of the traditional determinants on employment growth. The long-term elasticity of real labour costs is 0.44 over the period 1971Q3-2002Q2 and 0.34 when estimated over 1971Q3-1996Q4. As a robustness check, we obtained a broadly similar elasticity, 0.55 and 0.40 for the two periods mentioned earlier, when estimating equation (1) in one step, allowing for joint estimation of the long-run effects with dynamic effects. A Cobb-Douglas specification has been tested and clearly rejected. In such a frame, the long-term elasticity of employment to real labour costs is (minus) unity and there is no time trend. First, the error correction mechanism, which is equal to the logarithm of real unit 
labour costs with a Cobb-Douglas production function ${ }^{25}$, turns out to be clearly non stationary with the Dickey-Fuller and Phillip-Perron unit root tests. Moreover, a simple panel data estimate of labour demand indicates that the long-term elasticity ${ }^{26}$ of employment to real labour costs is -0.35 and constraining it to 1 is largely rejected by a Wald test (see Table 13 below). The long-term elasticity of employment to GDP is estimated to be 0.97 and constraining it to unity is largely accepted. All in all, the results of the euro area equation are confirmed using a panel data approach.

Table 13

Panel data estimates of employment in euro area countries

Dependent variable: annual employment growth

Explanatory variables expressed in annual growth (12 euro area countries. 1977-2001)

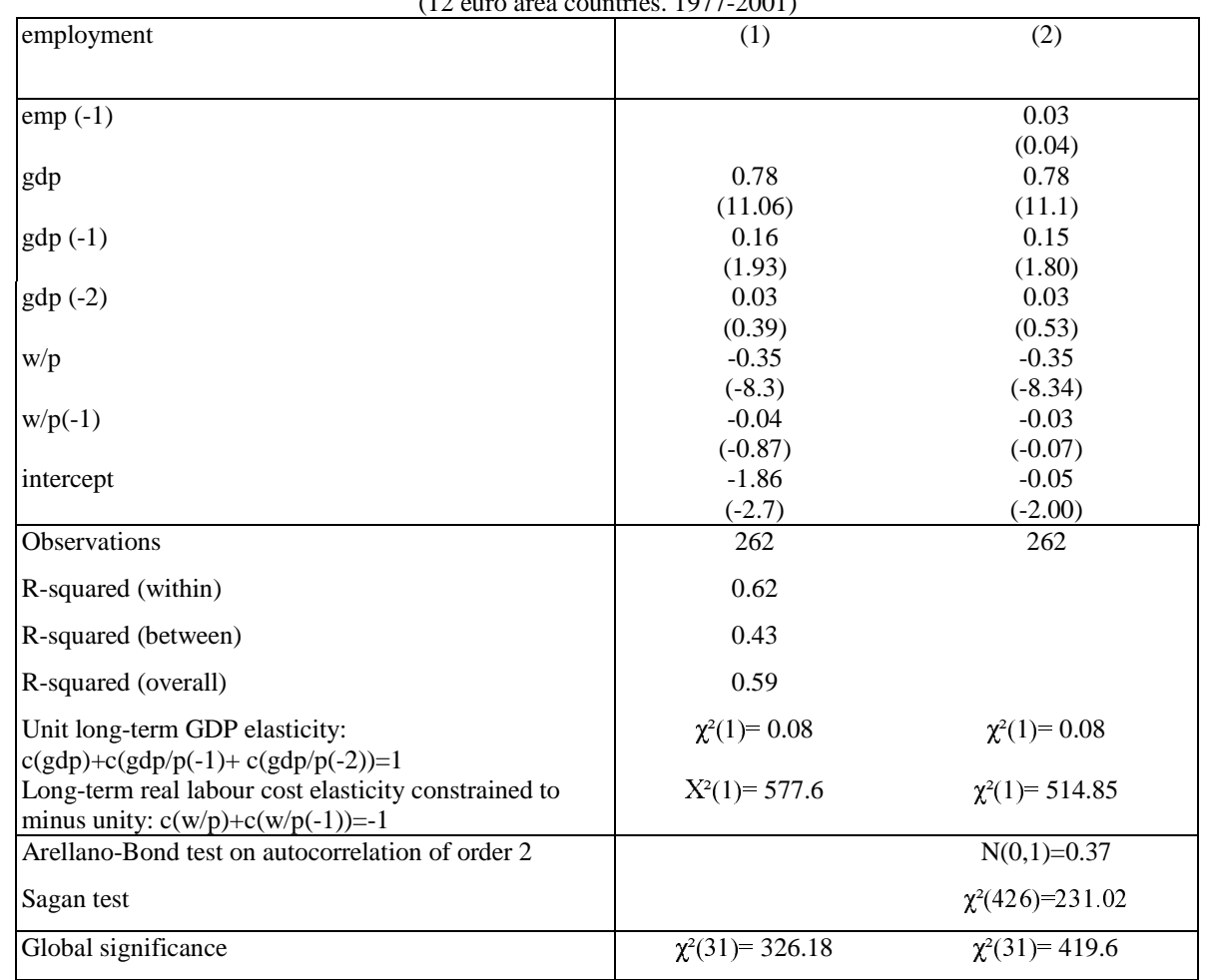

Sources: OECD economic outlook. Author's calculation.

Note: Equation (1) is estimated by fixed-effects (within) regression and contains time dummies. As a robustness check, equation (2) is estimated with variables in first difference by instrumental variables using the dynamic panel estimator package (DPD) developed by Arellano and Bond (1991), which derives a Generalised Method of Moments estimator. The Sargan test of over-identifying restrictions, which follows a chi-squared with 426 degrees of freedom, is clearly accepted with a p-value of 0.99. This means that the instruments (in excess of the regressors) are valid. The $R$ squared is not reported for equation (2) as it is not comparable to that of equation (1) given equation (2) refers to first-differences. Equations (1) and (2) contain time dummies. For equations 1 and 2, GDP and w/p have been instrumented in order to overcome endogeneity problems. The list of instruments is the contemporaneous export of goods and services and contemporaneous investments. As the explanatory variables are expressed in annual growth rates, the time trend becomes an intercept. The panel is unbalanced (data for Luxembourg and Portugal are available from the early 1990s only). Regressions start in 1977, as some variables, especially the instruments, are not available before for many countries.

${ }^{25}$ The error correction mechanism may be rewritten as: $E C M=\ln E-\ln Y+\ln (w / p)=\ln ((w / p) /(Y / E))=\ln (U L C / p)$, where $U L C$ means nominal unit labour costs.

${ }^{26}$ The long-term elasticity is the sum of the contemporaneous elasticity and that of all significant lags. 
Concerning the stability of the equation, evidence is mixed. The coefficients appear very stable up to 1997 but vary henceforth. The Chow forecast test with diverse break points does not allow for rejecting the hypothesis of stability. The CUSUM test (Brown, Durbin, and Evans, 1975), based on the cumulative sum of the recursive residuals, confirms that the equation is broadly stable over the estimation period. As shown by Figure 1, dynamic simulations from equation (1) estimated over 1971Q3-1996Q4 appear satisfactory in the 1970s, 1980s and early 1990, but underestimate the magnitude in employment variation in the late 1990s. Conversely, the dynamic simulation obtained from equation (1) estimated over the full period is fairly mediocre, especially from 1991, which might signal some instability at the end of the period, as confirmed by the recursive estimates of the coefficient.

The equation appears unstable at the end of the estimation period. The recursive estimates of the coefficients are very stable up to 1997 but vary henceforth. As shown by Figure 1, dynamic simulations from equation (1) of Table 3 estimated over 1971Q3-1996Q4 appear satisfactory in the 1970s, 1980s and early 1990, but underestimate the magnitude in employment variation in the late 1990s. Conversely, the dynamic simulation obtained from equation (1) estimated over the full period is fairly mediocre, especially from 1991, which seems to confirm the instability at the end of the period. 


\section{European Central Bank working paper series}

For a complete list of Working Papers published by the ECB, please visit the ECB's website (http://www.ecb.int).

302 “Deposit insurance, moral hazard and market monitoring” by R. Gropp and J. Vesala, February 2004.

303 "Fiscal policy events and interest rate swap spreads: evidence from the EU" by A. Afonso and R. Strauch, February 2004.

304 “Equilibrium unemployment, job flows and inflation dynamics" by A. Trigari, February 2004.

305 "A structural common factor approach to core inflation estimation and forecasting" by C. Morana, February 2004.

306 "A markup model of inflation for the euro area” by C. Bowdler and E. S. Jansen, February 2004.

307 "Budgetary forecasts in Europe - the track record of stability and convergence programmes" by R. Strauch, M. Hallerberg and J. von Hagen, February 2004.

308 "International risk-sharing and the transmission of productivity shocks" by G. Corsetti, L. Dedola and S. Leduc, February 2004.

309 "Monetary policy shocks in the euro area and global liquidity spillovers" by J. Sousa and A. Zaghini, February 2004.

310 "International equity flows and returns: A quantitative equilibrium approach" by R. Albuquerque, G. H. Bauer and M. Schneider, February 2004.

311 "Current account dynamics in OECD and EU acceding countries - an intertemporal approach" by M. Bussière, M. Fratzscher and G. Müller, February 2004.

312 "Similarities and convergence in G-7 cycles" by F. Canova, M. Ciccarelli and E. Ortega, February 2004.

313 "The high-yield segment of the corporate bond market: a diffusion modelling approach for the United States, the United Kingdom and the euro area" by G. de Bondt and D. Marqués, February 2004.

314 "Exchange rate risks and asset prices in a small open economy" by A. Derviz, March 2004.

315 "Option-implied asymmetries in bond market expectations around monetary policy actions of the ECB" by S. Vähämaa, March 2004. 
316 “Cooperation in international banking supervision” by C. Holthausen and T. Rønde, March 2004.

317 “Fiscal policy and inflation volatility" by P. C. Rother, March 2004.

318 "Gross job flows and institutions in Europe” by R. Gómez-Salvador, J. Messina and G. Vallanti, March 2004.

319 “Risk sharing through financial markets with endogenous enforcement of trades” by T. V. Köppl, March 2004.

320 "Institutions and service employment: a panel study for OECD countries" by J. Messina, March 2004.

321 "Frequency domain principal components estimation of fractionally cointegrated processes" by C. Morana, March 2004.

322 "Modelling inflation in the euro area" by E. S. Jansen, March 2004.

323 "On the indeterminacy of New-Keynesian economics" by A. Beyer and R. E. A. Farmer, March 2004.

324 "Fundamentals and joint currency crises" by P. Hartmann, S. Straetmans and C. G. de Vries, March 2004.

325 "What are the spill-overs from fiscal shocks in Europe? An empirical analysis" by M. Giuliodori and R. Beetsma, March 2004.

326 "The great depression and the Friedman-Schwartz hypothesis" by L. Christiano, R. Motto and M. Rostagno, March 2004.

327 "Diversification in euro area stock markets: country versus industry" by G. A. Moerman, April 2004.

328 "Non-fundamental exchange rate volatility and welfare" by R. Straub and I. Tchakarov, April 2004.

329 "On the determinants of euro area FDI to the United States: the knowledge-capital-Tobin's Q framework, by R. A. De Santis, R. Anderton and A. Hijzen, April 2004.

330 "The demand for euro area currencies: past, present and future" by B. Fischer, P. Köhler and F. Seitz, April 2004.

33I "How frequently do prices change? evidence based on the micro data underlying the Belgian CPI" by L. Aucremanne and E. Dhyne, April 2004.

332 "Stylised features of price setting behaviour in Portugal: 1992-200I" by M. Dias, D. Dias and P. D. Neves, April 2004.

333 "The pricing behaviour of Italian firms: New survey evidence on price stickiness" by S. Fabiani, A. Gattulli and R. Sabbatini, April 2004.

334 "Is inflation persistence intrinsic in industrial economies?" by A. T. Levin and J. M. Piger, April 2004.

335 "Has eura-area inflation persistence changed over time?" by G. O'Reilly and K. Whelan, April 2004.

336 "The great inflation of the 1970s" by F. Collard and H. Dellas, April 2004.

337 "The decline of activist stabilization policy: Natural rate misperceptions, learning and expectations" by A. Orphanides and J. C. Williams, April 2004. 
338 "The optimal degree of discretion in monetary policy" by S. Athey, A. Atkeson and P. J. Kehoe, April 2004.

339 “Understanding the effects of government spending on consumption” by J. Galí, J. D. López-Salido and J. Vallés, April 2004.

340 "Indeterminacy with inflation-forecast-based rules in a two-bloc model" by N. Batini, P.Levine and J. Pearlman, April 2004.

34I "Benefits and spillovers of greater competition in Europe: A macroeconomic assessment" by T. Bayoumi, D. Laxton and P. Pesenti, April 2004.

342 "Equal size, equal role? Interest rate interdependence between the euro area and the United States" by M. Ehrmann and M. Fratzscher, April 2004.

343 "Monetary discretion, pricing complementarity and dynamic multiple equilibria” by R. G. King and A. L. Wolman, April 2004.

344 "Ramsey monetary policy and international relative prices” by E. Faia and T. Monacelli, April 2004.

345 "Optimal monetary and fiscal policy: A linear-quadratic approach" by P. Benigno and M. Woodford, April 2004.

346 "Perpetual youth and endogenous labour supply: a problem and a possible solution" by G. Ascari and N. Rankin, April 2004.

347 "Firms' investment decisions in response to demand and price uncertainty" by C. Fuss and P. Vermeulen, April 2004.

348 "Financial openness and growth: Short-run gain, long-run pain?" by M. Fratzscher and M. Bussiere, April 2004.

349 "Estimating the rank of the spectral density matrix" by G. Camba-Mendez and G. Kapetanios, April 2004.

350 "Exchange-rate policy and the zero bound on nominal interest rates" by G. Camba-Mendez and G. Kapetanios, April 2004.

35I "Interest rate determination in the interbank market" by V. Gaspar, G. P. Quirós and H. R. Mendizábal, April 2004.

352 "Forecasting inflation with thick models and neural networks" by P. McNelis and P. McAdam, April 2004.

353 "Towards the estimation of equilibrium exchange rates for CEE acceding countries: methodological issues and a panel cointegration perspective” by F. Maeso-Fernandez, C. Osbat and B. Schnatz, April 2004.

354 "Taking stock: monetary policy transmission to equity markets” by M. Ehrmann and M. Fratzscher, May 2004.

355 "Production interdependence and welfare" by K. X. D. Huang and Z. Liu, May 2004. 
356 "Developing a euro area accounting matrix: issues and applications" by T. Jellema, S. Keuning, P. McAdam and R. Mink, May 2004.

357 "Seasonal adjustment and the detection of business cycle phases" by A. M. Mir, and D. R. Osborn, May 2004.

358 "Did the pattern of aggregate employment growth change in the euro area in the late 1990s?" by G. Mourre, May 2004. 
